\title{
Selected Metals in Sediments and Streams in the Oklahoma Part of the Tri-State Mining District, 2000-2006
}

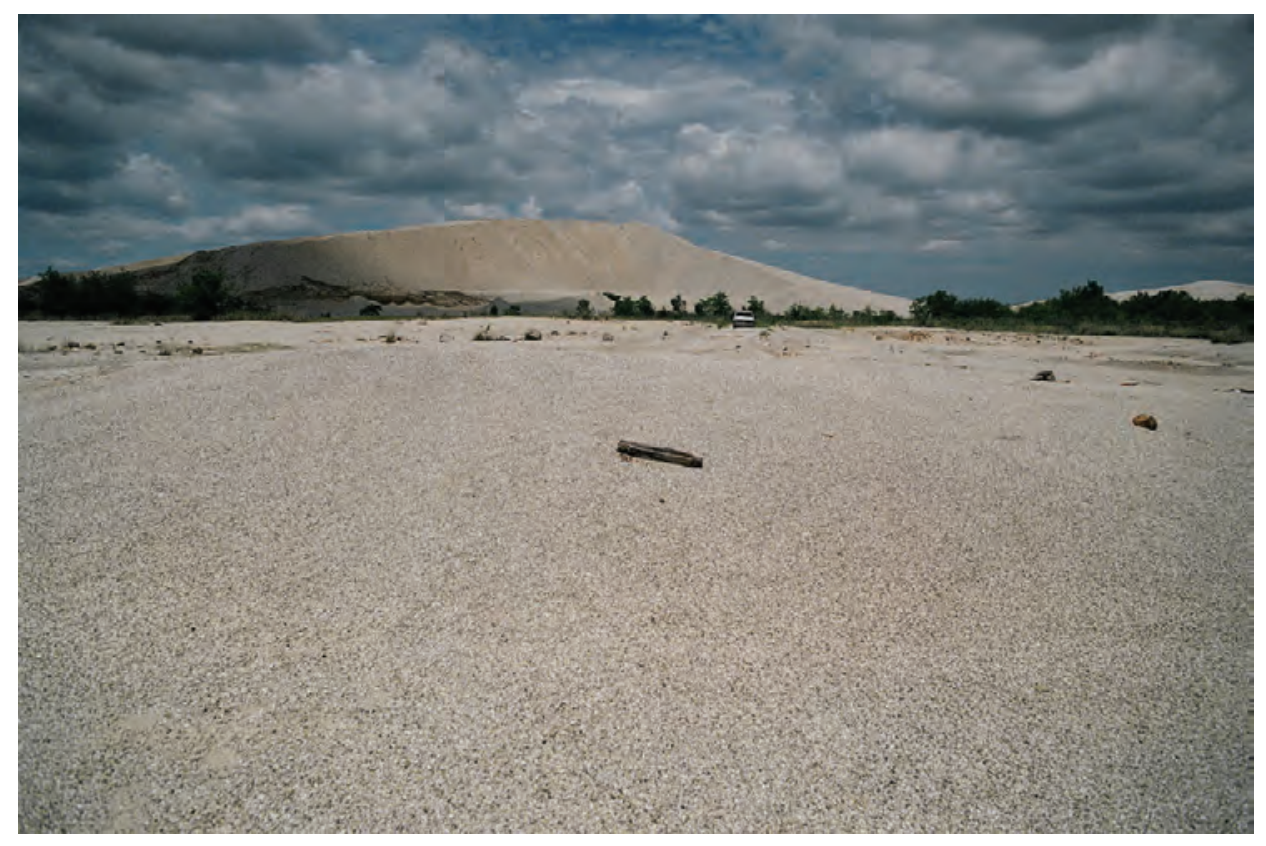

Scientific Investigations Report 2009-5032 
On the cover: Photograph of chat piles in the Tri-State mining district in Picher, Oklahoma.

Photograph taken by William Andrews, U.S. Geological Survey. (Photograph taken by William J. Andrews on June 1, 2006.) 


\section{Selected Metals in Sediments and Streams in the Oklahoma Part of the Tri-State Mining District, 2000-2006}

By William J. Andrews, Mark F. Becker, Shana L. Mashburn, and S. Jerrod Smith

Scientific Investigations Report 2009-5032 


\title{
U.S. Department of the Interior \\ KEN SALAZAR, Secretary
}

\author{
U.S. Geological Survey \\ Suzette M. Kimball, Acting Director
}

U.S. Geological Survey, Reston, Virginia: 2009

For more information on the USGS - the Federal source for science about the Earth, its natural and living resources, natural hazards, and the environment, visit http://www.usgs.gov or call 1-888-ASK-USGS

For an overview of USGS information products, including maps, imagery, and publications, visit http://www.usgs.gov/pubprod

To order this and other USGS information products, visit http://store.usgs.gov

Any use of trade, product, or firm names is for descriptive purposes only and does not imply endorsement by the U.S. Government.

Although this report is in the public domain, permission must be secured from the individual copyright owners to reproduce any copyrighted materials contained within this report.

Suggested citation:

Andrews, W.J., Becker, M.F., Mashburn, S.L., and Smith, S.J., 2009, Selected metals in sediments and streams in the Oklahoma part of the Tri-State mining district, 2000-2006: U.S. Geological Survey Scientific Investigations Report 2009-5-032, $36 \mathrm{p}$ 


\section{Contents}

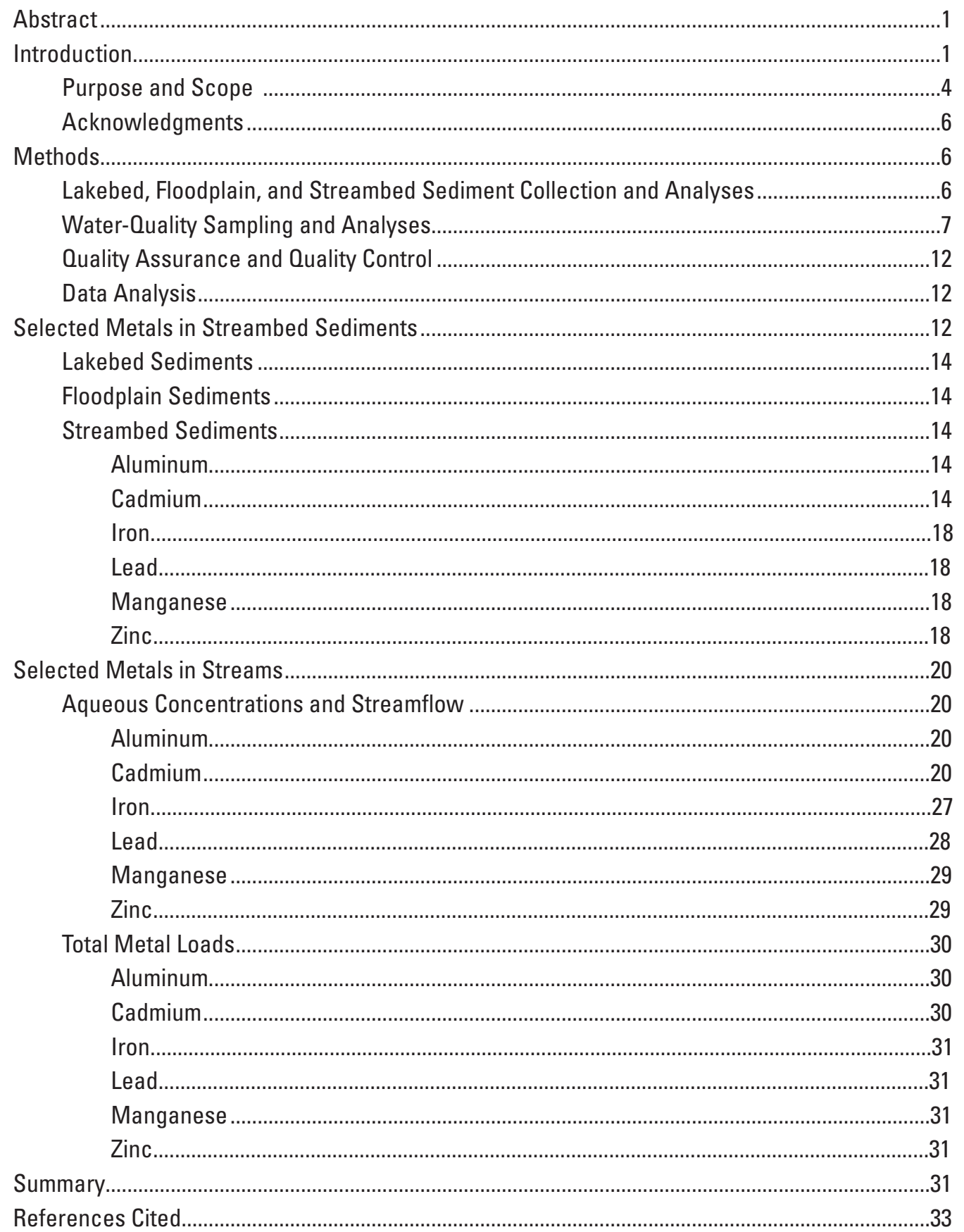




\section{Figures}

1. Map showing location of mining areas in the Tri-State mining district of Oklahoma, Kansas, and Missouri.......

2. Photographs of (A) a tailings pile near Picher, Oklahoma, (B) millpond tailings near Douthat, Oklahoma, (C) iron-hydroxide-stained water along a ditch draining to Tar Creek near Douthat, Oklahoma, and (D) deposits of soft, flocculated botryoidal goethite and other iron oxide and hydroxide minerals on the streambed of Tar Creek near Douthat, Oklahoma.

3. Map showing location of water-quality and sediment sample collection sites in the Oklahoma part of the Tri-State mining district, 2000-2006.

4. Aerial photograph of location of sites sampled for sediments in the upstream part of Grand Lake 0' the Cherokees, April 2002 and April 2004.

5. Photographs of measurement and processing of sediment cores collected in the upstream end of Grand Lake 0' the Cherokees in April 2004.

6. Map showing locations of sediment cores collected on the floodplain of Tar Creek south of the 22nd Street Bridge in Miami, Oklahoma, on June 16, 2004.

7. Boxplots of relative percent differences for concentrations of $(A)$ selected metals in streambed sediment, and (B) water duplicate samples collected in the Oklahoma part of the Tri-State mining district, 2000-06.

8. Bar graphs of selected metals concentrations in streambed samples collected at sites in the upstream end of Grand Lake 0' the Cherokees, April 2002 and April 2004

9. Cross-sectional diagrams showing distributions of concentrations of $(A)$ aluminum, (B) cadmium, (C) iron, (D) lead, (E) manganese, and (F) zinc in sediment cores collected in a transect 165 feet south of the 22nd Street Bridge at Tar Creek at Miami, Oklahoma, on June 16, 2004 .

10-11. Boxplots showing:

10. Ranges of concentrations of selected metals in streambed sediment samples from six stream sites in the Oklahoma part of the Tri-State mining district,2004-06. .....17

11. Ranges of concentrations of dissolved oxygen and of $\mathrm{pH}$ in water-quality samples from 18 stream sites in the Oklahoma part of the Tri-State mining district 2004-06. ......19

12-18. Graphs showing:

12. Ranges in concentrations of total and dissolved aluminum $(A)$, and graphs of total concentrations of aluminum in surface-water samples compared to discharge $(B, C)$ for samples collected at sites in the Oklahoma part of the Tri-State mining district, 2000-06. .

13. Ranges in concentrations of total and dissolved cadmium (A), and graphs of total concentrations of cadmium in surface-water samples compared to discharge $(B, C)$ for samples collected at sites in the Oklahoma part of the Tri-State mining district, 2000-06. .

14. Ranges in concentrations of total and dissolved iron (A), and graphs of total concentrations of iron in surface-water samples compared to discharge $(B, C)$ for samples collected at sites in the Oklahoma part of the Tri-State mining district, 2000-06.

15, Ranges in concentrations of total and dissolved lead (A), and graphs of total concentrations of lead in surface-water samples compared to discharge $(B, C)$ for samples collected at sites in the Oklahoma part of the Tri-State mining district, 2000-06.

16. Ranges in concentrations of total and dissolved manganese (A), and graphs of total 
concentrations of manganese in surface-water samples compared to discharge $(B, C)$ for samples collected at sites in the Oklahoma part of the Tri-State mining district, 2000-06.

17. Ranges in concentrations of total and dissolved zinc $(A)$, and graphs of total concentrations of zinc in surface-water samples compared to discharge $(B, C)$ for samples collected at sites in the Oklahoma part of the Tri-State mining district, 2000-06

18. Ranges of loads of total aluminum, cadmium, iron, lead, manganese, and zinc in surface-water samples collected at sites in the Oklahoma part of the Tri-State mining district, 2000-06.

\section{Tables}

1. Concentrations of selected metals in a tailings sample from the Kennoyer North pile and two millpond tailings samples collected near Cardin, Oklahoma in 2004.

2. U.S. Geological Survey investigations in the Oklahoma portion of the Tri-State mining district, 2000-06 .6

3. Lakebed sediment sampling sites in the upstream end of Grand Lake 0 ' the Cherokees (April 2002 and April 2004).

4. Locations and depths of floodplain sediment cores collected along a transect near Tar Creek at the 22nd Street Bridge at Miami, Oklahoma gaging station on June 16, 2004.

5. Stream sites sampled for water quality and streambed sediment in the Oklahoma part of the Tri-State mining district, 2000-06.

6. Regression equations used to estimate streamflow at time of water-quality sampling at selected stream sites in the Oklahoma part of the Tri-State mining district, 2000-06

7. Mined areas compared to basin areas for selected basins in the Oklahoma part of the Tri-State mining district. 


\section{Conversion Factors and Datums}

\begin{tabular}{|c|c|c|}
\hline Multiply & By & To obtain \\
\hline \multicolumn{3}{|c|}{ Length } \\
\hline inch (in.) & 2.54 & centimeter $(\mathrm{cm})$ \\
\hline foot (ft) & 0.3048 & $\operatorname{meter}(\mathrm{m})$ \\
\hline mile (mi) & 1.609 & kilometer (km) \\
\hline \multicolumn{3}{|c|}{ Area } \\
\hline square mile $\left(\mathrm{mi}^{2}\right)$ & 2.590 & square kilometer $\left(\mathrm{km}^{2}\right)$ \\
\hline \multicolumn{3}{|c|}{ Volume } \\
\hline gallon (gal) & 3.785 & liter (L) \\
\hline cubic foot $\left(\mathrm{ft}^{3}\right)$ & 0.02832 & cubic meter $\left(\mathrm{m}^{3}\right)$ \\
\hline cubic yard $\left(\mathrm{yd}^{3}\right)$ & 0.7646 & cubic meter $\left(\mathrm{m}^{3}\right)$ \\
\hline \multicolumn{3}{|c|}{ Flow rate } \\
\hline cubic foot per second $\left(\mathrm{ft}^{3} / \mathrm{s}\right)$ & 0.02832 & cubic meter per second $\left(\mathrm{m}^{3} / \mathrm{s}\right)$ \\
\hline \multicolumn{3}{|c|}{ Mass } \\
\hline pound (lb) & 0.4536 & kilogram (kg) \\
\hline ton, short $(2,000 \mathrm{lb})$ & 0.9072 & megagram (Mg) \\
\hline
\end{tabular}

Vertical coordinate information is referenced to the National Geodetic Vertical Datum of 1929 (NGVD 29).

Horizontal coordinate information is referenced to the North American Datum of 1983 (NAD 83).

Concentrations of chemical constituents in sediment are given in milligrams per kilogram $(\mathrm{mg} / \mathrm{Kg}$ equivalent to parts per million) and in water in micrograms per liter $(\mu \mathrm{g} / \mathrm{L}$, equivalent to parts per billion).

Minimum reporting level (MRL) - Smallest measured concentration of a constituent that may be reliable reported by using a given method (Timme, 1995). 


\title{
Selected Metals in Sediments and Streams in the Oklahoma Part of the Tri-State Mining District, 2000-2006
}

\author{
By William J. Andrews, Mark F. Becker, Shana L. Mashburn, and S. Jerrod Smith
}

\section{Abstract}

The abandoned Tri-State mining district includes 1,188 square miles in northeastern Oklahoma, southeastern Kansas, and southwestern Missouri. The most productive part of the Tri-State mining district was the 40-square mile part in Oklahoma, commonly referred to as "the Picher mining district" in north-central Ottawa County, Oklahoma. The Oklahoma part of the Tri-State mining district was a primary producing area of lead and zinc in the United States during the first half of the 20th century. Sulfide minerals of cadmium, iron, lead, and zinc that remained in flooded underground mine workings and in mine tailings on the land surface oxidized and dissolved with time, forming a variety of oxide, hydroxide, and hydroxycarbonate metallic minerals on the land surface and in streams that drain the district. Metals in water and sediments in streams draining the mining district can potentially impair the habitat and health of many forms of aquatic and terrestrial life.

Lakebed, streambed and floodplain sediments and/or stream water were sampled at 30 sites in the Oklahoma part of the Tri-State mining district by the U.S. Geological Survey and the Oklahoma Department of Environmental Quality from 2000 to 2006 in cooperation with the U.S. Environmental Protection Agency, and the Quapaw and Seneca-Cayuga Tribes of Oklahoma. Aluminum and iron concentrations of several thousand milligrams per kilogram were measured in sediments collected from the upstream end of Grand Lake O' the Cherokees. Manganese and zinc concentrations in those sediments were several hundred milligrams per kilogram. Lead and cadmium concentrations in those sediments were about 10 percent and 0.1 percent of zinc concentrations, respectively. Sediment cores collected in a transect across the floodplain of Tar Creek near Miami, Oklahoma, in 2004 had similar or greater concentrations of those metals than sediment cores collected at the upstream end of Grand Lake O' the Cherokees. The greatest concentrations of cadmium, iron, lead, and zinc were detected in sediments beneath an intermittent tributary to Tar Creek, a slough which drains mined areas near Commerce, Oklahoma.

In surface water, aluminum and iron concentrations were greatest in the Neosho River, perhaps a result of runoff from areas underlain by shales. The greatest aqueous concentrations of cadmium, lead, manganese, and zinc were measured in water from Tar Creek, the primary small stream draining the Picher mining district with the largest proportion of mined area. Water from the Spring River had greater zinc concentrations than water from the Neosho River, perhaps as a result of a greater proportion of mined area in the Spring River Basin. Dissolved metals concentrations were generally much less than total metals concentrations, except for manganese and zinc at sites on Tar Creek, where seepage of ground water from the mine workings, saturated mine tailings, and/or metalliferous streambed sediments may be sources of these dissolved metals. Iron and lead concentrations generally decreased with increasing streamflow in upstream reaches of Tar Creek, indicating dilution of metals-rich ground water by runoff. Farther downstream in Tar Creek, and in the Neosho and Spring Rivers, metals concentrations tended to increase with increasing streamflow, indicating that most metals in these parts of these streams were associated with runoff and re-suspension of metals precipitated as oxide, hydroxide, and hydroxycarbonate minerals on land surface and streambeds.

Estimated total aluminum, cadmium, iron, manganese, and zinc loads generally were greatest in water from the Neosho and Spring Rivers, primarily because of comparatively large streamflows in those rivers. Slight increases in metal loads in the downstream directions on those rivers indicated contributions of metals from inflows of small tributaries such as Tar Creek and from runoff.

\section{Introduction}

The abandoned Tri-State mining district (fig. 1), an 1,188-square-mile area in northeast Oklahoma, southeast Kansas, and southwest Missouri, was the most productive site of lead and zinc mining in the U.S. from the late 1830 s to the 1970 s, producing about 1.7 million tons of lead and 8.8 million tons of zinc (Gibson, 1972; Gibson, 1982; State of Oklahoma, 2000a; Robertson, 2006). Ore production in the mining district was active from the late 1800 s until the mid1970s. Production reached a peak by 1925 with 387,000 tons of recoverable zinc and 101,000 tons of recoverable lead being produced. The mines maintained moderate production levels until the 1950s when yields began to decline. 
Parts of the mining district, included in the initial 1983 National Priority list of Superfund sites by the U.S. Environmental Protection Agency, are plagued by some of the most severe or widespread environmental degradation of any of the tens of thousands of abandoned mining sites in the United States (Ferderer, 1996; State of Oklahoma, 2000a; Robertson, 2006). One of the most productive parts of the Tri-State mining district (fig. 1) was the Picher mining district, a 40-squaremile area in north-central Ottawa County, Oklahoma. This area comprises most of the mined land in the Tri-State mining district, now the Tar Creek Superfund site, and is referred to as "the mining district" in this report.

When mining stopped in the mining district in the 1970s, as much as 165-300 million tons of mine tailings (waste rock, locally known as "chat"), some of which had been reprocessed one or more times to recover metals, were distributed in piles and ground cover (fig. 2, State of Oklahoma, 2000a). The U.S. Army Corps of Engineers, in 2000, estimated that 60 million cubic yards or 75 million tons of chat remained in the mining district (State of Oklahoma, 2000a). Ponds near many of the chat piles, filled with silt- and clay-sized by-products of the gravity-separation process, are referred to in this report as millpond tailings (fig. 2). Tailings in the mining district contain concentrations of tens to tens of thousands of milligrams per kilogram (mg/Kg) of metals, including aluminum, cadmium, iron, lead, manganese, and zinc, with the greatest concentrations of metals being associated with the finest particles (table 1, Datin and Cates, 2002; Schaider and others, 2007). Those fine particles with the greatest metals concentrations comprise the particles most susceptible to erosion (transport) by wind and water. Seeps from the flooded underground mine workings, and leachate and runoff from tailings discharge metals, in varying degrees, to local streams. After anoxic water rich in dissolved, reduced ferrous $\left(\mathrm{Fe}+{ }^{2}\right)$ iron seeps from the underground mines to the land surface, iron is oxidized, precipitating as deposits of amorphous orange iron oxide and hydroxide minerals (fig. 2). Other metals such as lead and zinc, also gradually dissolve from sulfide minerals in the mine workings and in tailings on the land surface, oxidizing to form a variety of oxide, hydroxide, and hydroxycarbonate minerals that precipitate on the land surface and in local streambeds (Hem, 1992; Morel and Hering, 1993; American Water Works Association Research Foundation, 1996; Carroll and others, 1998; O'Day and others, 1998; Schaider and others, 2007). Several metals, including lead and zinc, also can be adsorbed onto clay minerals and iron and manganese oxides on the land surface and in streams (Drever, 1988; Hem, 1992), making many metals subject to transport in land-surface runoff and re-suspension from streambed sediments during high streamflows.

Table 1. Concentrations of selected metals in a tailings sample from the Kennoyer North pile and two millpond tailings samples collected near Cardin, Oklahoma in 2004.

[Analyses by digestion and ICP-MS, U.S. Geological Research Laboratory, Denver, Colorado, written commun., Stephen J. Sutley, 2005]

\begin{tabular}{|c|c|c|c|}
\hline \multirow[b]{2}{*}{ Metal } & \multicolumn{2}{|c|}{ Kennoyer North pile tailings } & \multirow[b]{2}{*}{$\begin{array}{c}\text { Mean of two millpond } \\
\text { tailings samples, metal } \\
\text { concentration, in milligrams } \\
\text { per kilogram }\end{array}$} \\
\hline & $\begin{array}{l}\text { Unsieved concentration, } \\
\text { in milligrams per kilogram }\end{array}$ & $\begin{array}{c}\text { Sieved concentration (par- } \\
\text { ticles than } 2 \text { millimeters } \\
\text { in diameter), in milligrams } \\
\text { per kilogram }\end{array}$ & \\
\hline Aluminum & 1,700 & 4,100 & 20,300 \\
\hline Cadmium & 12.9 & 31.2 & 119 \\
\hline Iron & 1,690 & 4,080 & 16,900 \\
\hline Lead & 369 & 890 & 9,180 \\
\hline Manganese & 13.8 & 33.2 & 158 \\
\hline Zinc & 3,630 & 8,750 & 22,300 \\
\hline
\end{tabular}




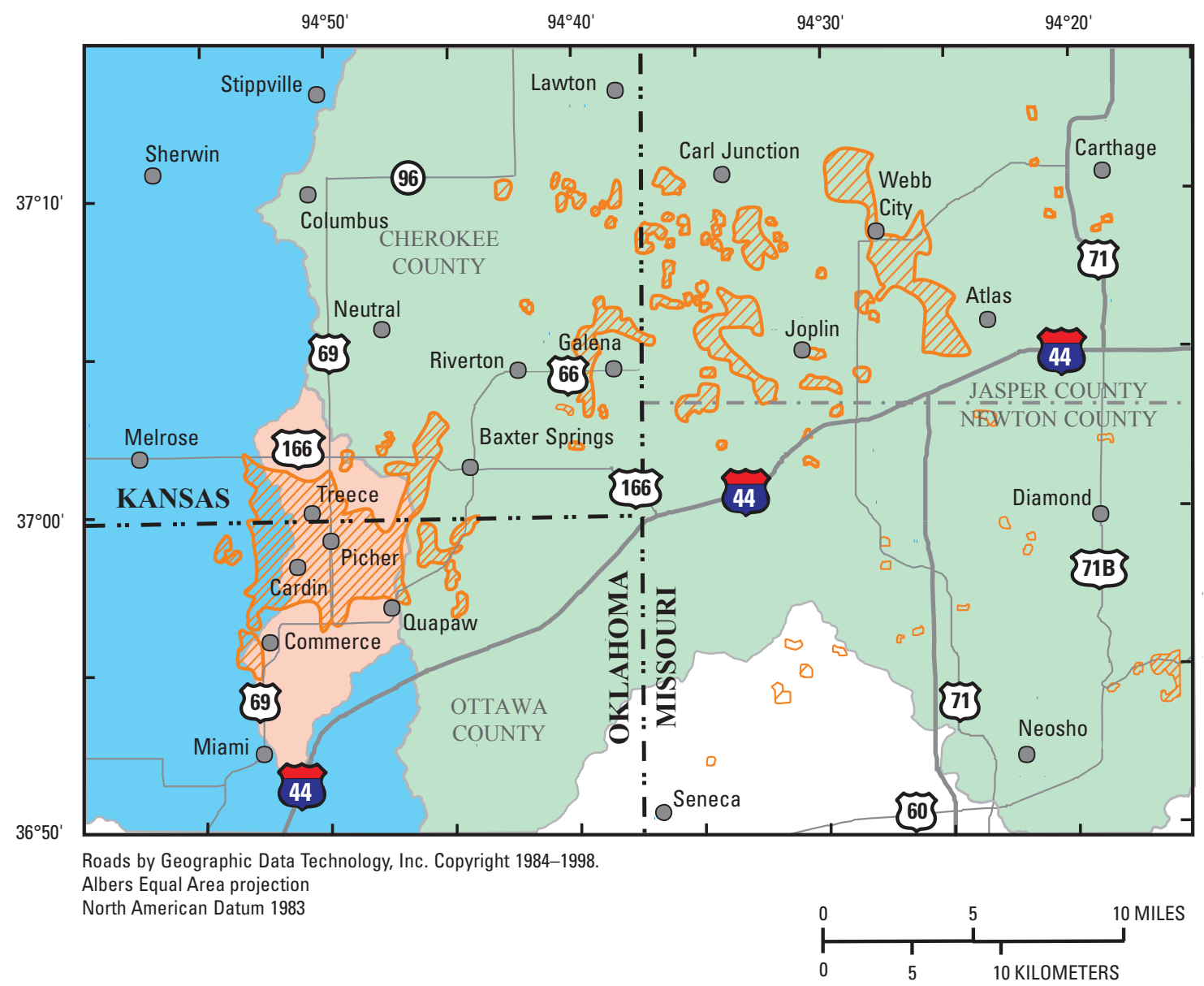

\section{EXPLANATION}

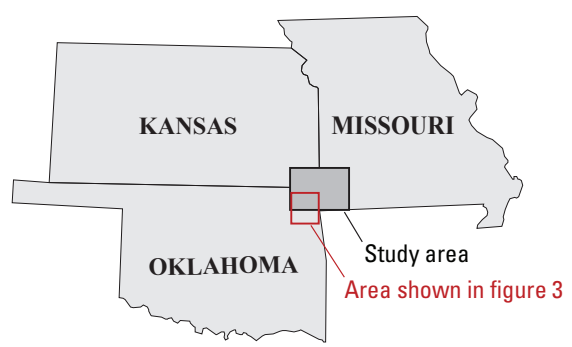

Figure 1. Location of mining areas in the Tri-State mining district of Oklahoma, Kansas, and Missouri. 
A

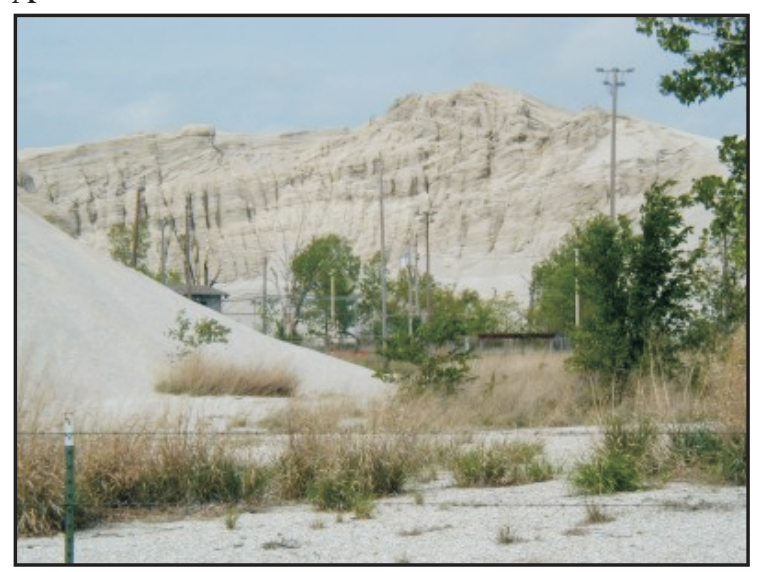

B

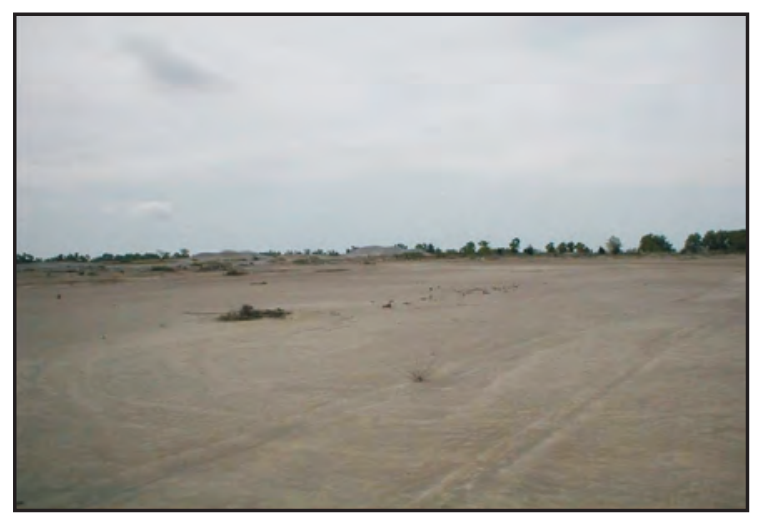

$\mathrm{C}$

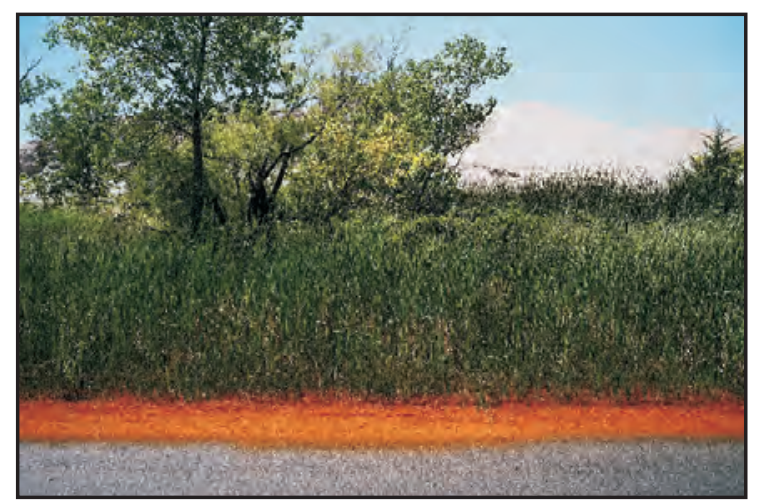

$\mathrm{D}$

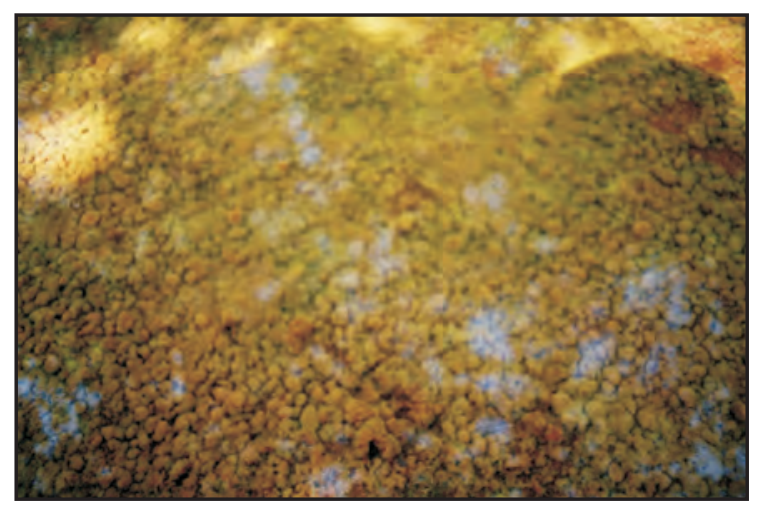

Figure 2. Photographs of $(A)$ a tailings pile near Picher, Oklahoma, (B) millpond tailings near Douthat, Oklahoma, (C) iron-hydroxide-stained water along a ditch draining to Tar Creek near Douthat, Oklahoma, and (D) deposits of soft, flocculated botryoidal goethite and other iron oxide and hydroxide minerals on the streambed of Tar Creek near Douthat, Oklahoma, (photographs A, B, and D by William J. Andrews, U.S. Geological Survey; photograph B by R.W. Nairn, University of Oklahoma).

Most of the mining in this mining district took place below the water table, necessitating continuous pumping of ground water to prevent flooding of the workings. Water from dewatering operations was discharged to local streams. More than 13 million gallons of water were pumped from the mines during production in the 1930 s to 1940 s (Reed and others, 1955 , p. 53-54), but no information is available regarding metals concentrations in water discharged to local streams during mining. Prior to cessation of mining in the 1970s, dewatering operations ended and the mine workings refilled with ground water. After the mines filled with ground water, seeps of acidic water with large concentrations of metals started to flow from abandoned mine shafts, vent holes, dewatering wells, and collapsed areas in late 1979 (State of Oklahoma, 2002). Exacerbating the problem, parts of Tar and Lytle Creeks (fig. 3) flowed into collapses, increasing the flow of water through the mine workings. Fate and transport of metals from leachate and discharges from the flooded mine workings are poorly understood, particularly for the period prior to 1980.

\section{Purpose and Scope}

The purpose of this report is to summarize concentrations and/or loads of selected metals in samples of: (a) lakebed sediments, (b) floodplain sediments, (c) streambed sediments, and (d) surface-water samples collected from 2000 through 2006 at 30 sites in the mining district. Metals-concentration data from those samples were collected during several studies completed by the U.S. Geological Survey (USGS) and the Oklahoma Department of Environmental Quality (DEQ) in cooperation with: the Quapaw Tribe of Oklahoma (streamwater quality study in 2000), the Seneca-Cayuga Tribe of Oklahoma (lakebed sediment study in 2002 and 2004), the Oklahoma Department of Environmental Quality (floodplain sediment study in 2004, and streambed sediments and streamwater study from 2004-2006), and investigation of metals in ground-water seepage compared to runoff in upstream parts of Tar and Lytle Creeks (Cope and others, 2008). This report also describes metals loads transported by streams draining the mining district. Unpublished data from most of these studies 


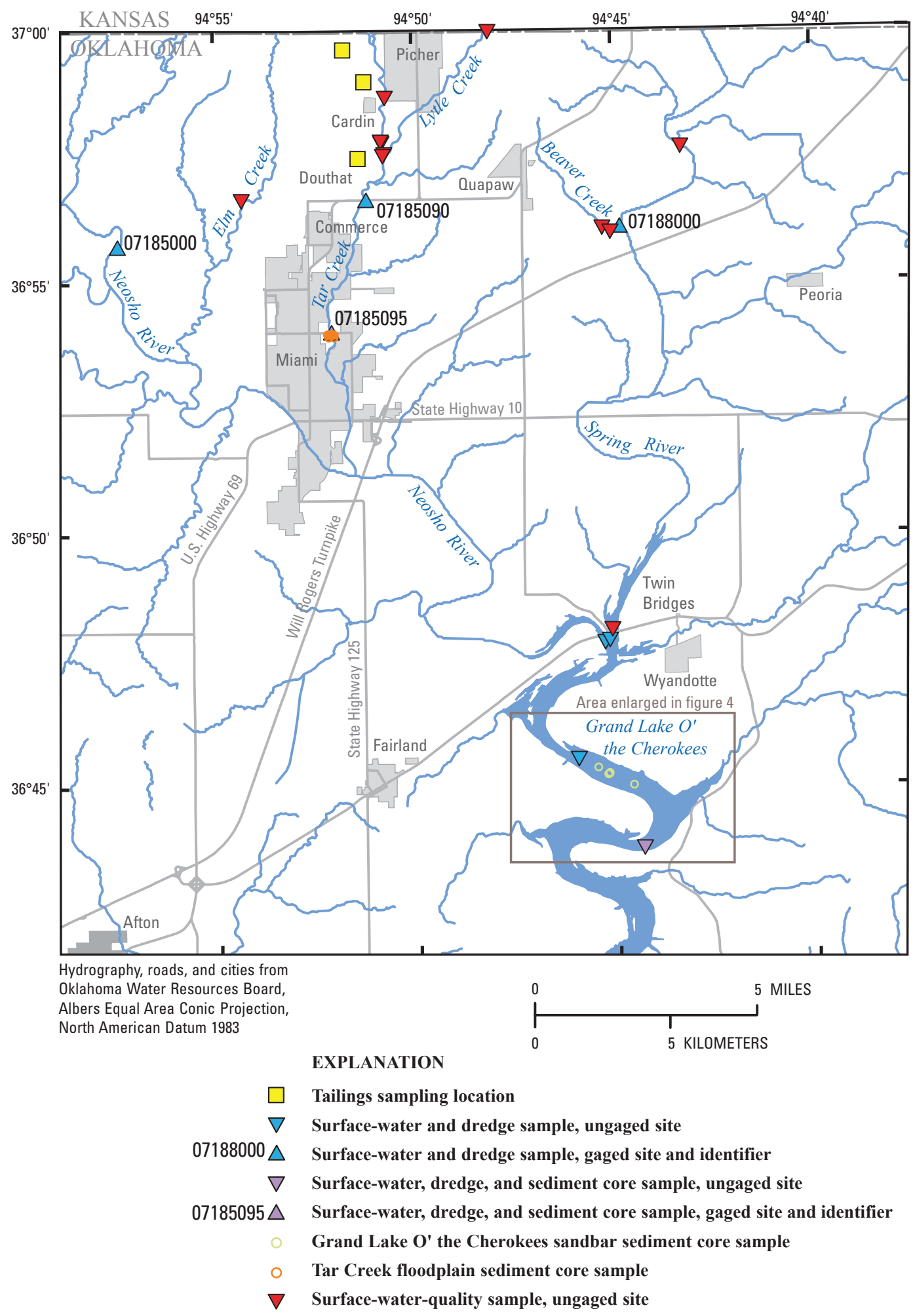

Figure 3. Location of water-quality and sediment sample collection sites in the Oklahoma part of the Tri-State mining district, 2000-2006. 
Table 2. U.S. Geological Survey investigations in the Oklahoma part of the Tri-State mining district, 2000-06.

\begin{tabular}{|c|c|c|}
\hline Cooperator & Years & Data-collection activity \\
\hline Quapaw Tribe of Oklahoma & 2000 & $\begin{array}{l}\text { Collect surface-water samples six times at five stream sites to investi- } \\
\text { gate concentrations of total metals and other constituents (summary } \\
\text { at http://ok.water.usgs.gov/quapaw/). }\end{array}$ \\
\hline $\begin{array}{l}\text { Seneca-Cayuga Tribe } \\
\text { of Oklahoma }\end{array}$ & $\begin{array}{l}2002 \\
2004\end{array}$ & $\begin{array}{l}\text { Obtain and analyze lake sediment for metals from the upstream end of } \\
\text { Grand Lake O' the Cherokees }\end{array}$ \\
\hline \multirow[t]{2}{*}{$\begin{array}{l}\text { Oklahoma Department } \\
\text { of Environmental Quality }\end{array}$} & \multirow[t]{2}{*}{2004} & $\begin{array}{l}\text { Obtain sediment cores in a transect across Tar Creek floodplain in } \\
\text { Miami, Oklahoma }\end{array}$ \\
\hline & & Have sediment samples analyzed for metals \\
\hline \multirow{2}{*}{$\begin{array}{l}\text { Oklahoma Department } \\
\text { of Environmental Quality }\end{array}$} & \multirow{2}{*}{ 2004-06 } & $\begin{array}{l}\text { Collect surface-water samples at high flows and sediments for metals } \\
\text { analysis }\end{array}$ \\
\hline & & $\begin{array}{l}\text { Oklahoma Department of Environmental Quality staff collected } \\
\text { water-quality samples at base flows. }\end{array}$ \\
\hline $\begin{array}{l}\text { U.S. Environmental } \\
\text { Protection Agency }\end{array}$ & 2005 & $\begin{array}{l}\text { Collect surface-water samples in Tar and Lytle Creeks to analyze for } \\
\text { flux of leachate from chat piles and mine discharge entering Tar } \\
\text { Creek (Cope and others, 2008) }\end{array}$ \\
\hline
\end{tabular}

are available in the USGS-National Water Information System database (http://waterdata.usgs.gov/nwis).

\section{Acknowledgments}

The author would like to thank all DEQ and USGS staff who collected data summarized in this report. Gratitude is extended to Tim Kresse, Michael Kleeshulte, Kim Winton, Stan Paxton, Lyn Osburn, and Keith Lucey for their helpful reviews of the report.

\section{Methods}

Several recent studies have been done by the USGS and DEQ in and downstream from the mining district (table 2). Those studies were done in cooperation with several State and Federal agencies and Native American Tribes. Sampling sites (fig. 3) extended from the mining district downstream into the upper parts of Grand Lake O’ the Cherokees.

\section{Lakebed, Floodplain, and Streambed Sediment Collection and Analyses}

Two lakebed sediment samples were collected by clamshell dredge (USGS sampler BM-54) from two sites in the upstream end of Grand Lake O' the Cherokees in April 2002 and April 2004 (table 2 and fig. 3) by using methods described in Radtke (1997). Sediment cores were collected at five additional sites on an exposed sandbar during the second sampling in April 2004 (fig. 3) by using a stainless steel corebarrel with a 2-inch polycarbonate core liner pushed to depths as much as 2 feet below the sandbar surface (table 3 ). The liner-encased core samples were removed from the core barrel, capped, and refrigerated (figs. 4 and 5). Core sub-sampling methods were followed to ensure minimal cross contamination at different sample depths. Core liners were cut open, with core material more than 0.4 inch from the edges being composited (fig. 5). Sediment samples collected in April 2002 and April 2004 were analyzed for concentrations of selected metals by the USGS National Water-Quality Laboratory in Lakewood, Colorado, (NWQL), by using microwave-assisted acid digestion (U.S. Environmental Protection Agency Method 3051A-revision 1) (U.S. Environmental Protection Agency, 1998) followed by metals analyses by inductively-coupled plasma-mass spectrometry, by using methods described in Garbarino and Struzeski (1998). Sediment samples were not segregated by particle-size distribution for the studies summarized in this report. Metals in tailings in the mining district tend to be most concentrated in the smallest particles, facilitating erosion and transport of metals by air and water (Datin and Cates, 2002; Schaider and others, 2007). USGS staff collected 12 sediment cores in a transect across the floodplain perpendicular to Tar Creek, the principle stream draining the mining district, about 165 feet south of the USGS gaging station (number 07185095) at the 22nd Street Bridge at Miami, Oklahoma, on June 16, 2004 (figs. 3, 5, and 6), to characterize concentrations of metals in sediments. Those core samples were obtained by using direct-push technology that 
Table 3. Lakebed sediment sampling sites in the upstream end of Grand Lake 0' the Cherokees (April 2002 and April 2004).

[NAD, North American Datum, sites listed from upstream to downstream]

\begin{tabular}{|c|c|c|c|c|}
\hline Site name & $\begin{array}{c}\text { USGS site } \\
\text { identification } \\
\text { number }\end{array}$ & $\begin{array}{l}\text { Latitude, and } \\
\text { longitude, in decimal } \\
\text { degrees }\end{array}$ & $\begin{array}{l}\text { Latitude and } \\
\text { longitude } \\
\text { datum }\end{array}$ & $\begin{array}{c}\text { Streambed } \\
\text { sediment } \\
\text { collection } \\
\text { depths, } \\
\text { in inches below } \\
\text { streambed surface }\end{array}$ \\
\hline $\begin{array}{c}\text { Grand Lake O' the } \\
\text { Cherokees near Wyandotte, } \\
\text { Oklahoma (Wyandotte) }\end{array}$ & 364532094460801 & $\begin{array}{c}\mathrm{N} 36.759, \\
\mathrm{~W}-094.769\end{array}$ & NAD27 & $\begin{array}{l}0-0.25 \text { (in 2002) } \\
0-2.00 \text { (in 2004) }\end{array}$ \\
\hline $\begin{array}{c}\text { Grand Lake O' the } \\
\text { Cherokees Sediment \#1 }\end{array}$ & 364520094453101 & $\begin{array}{c}\mathrm{N} 36.759, \\
\mathrm{~W}-094.759\end{array}$ & NAD83 & $0-36$ \\
\hline $\begin{array}{c}\text { Grand Lake O’ the } \\
\text { Cherokees Sediment \#2 }\end{array}$ & 364512094451501 & $\begin{array}{c}\mathrm{N} 36.754 \\
\mathrm{~W}-094.753\end{array}$ & NAD83 & $0-36$ \\
\hline $\begin{array}{c}\text { Grand Lake O' the Cherokees } \\
\text { Sediment \#3 }\end{array}$ & 364514094451401 & $\begin{array}{c}\mathrm{N} 36.754, \\
\mathrm{~W}-094.754\end{array}$ & NAD83 & $0-36$ \\
\hline $\begin{array}{c}\text { Grand Lake O' the } \\
\text { Cherokees Sediment \#4 }\end{array}$ & 364514094451401 & $\begin{array}{l}\mathrm{N} 36.754, \\
\mathrm{~W}-094.754\end{array}$ & NAD83 & $0-36$ \\
\hline $\begin{array}{c}\text { Grand Lake O' the } \\
\text { Cherokees Sediment \#5 }\end{array}$ & 364459094443801 & $\begin{array}{c}\mathrm{N} 36.750 \\
\mathrm{~W}-094.744\end{array}$ & NAD83 & $0-36$ \\
\hline $\begin{array}{l}\text { Grand Lake O' the Cherokees near } \\
\text { Fairland, Oklahoma } \\
\text { (Fairland) }\end{array}$ & 364344094442001 & $\begin{array}{l}\text { N36.729, } \\
\text { W-094.739 }\end{array}$ & NAD27 & $\begin{array}{l}0-0.25 \text { (in 2002) } \\
0-2.00 \text { (in 2004) }\end{array}$ \\
\hline
\end{tabular}

produced cores of 1.5 -inch diameter and as much as 3.5 feet in length (table 4 and fig. 6). Direct-push coring was completed to refusal (inability to further penetrate sediments). Similar processing and analyses methods were used for these sediment cores as were used for samples collected in hand cores on the sandbar in the upstream end of Grand Lake O' the Cherokees in April 2004.

USGS and DEQ staff also periodically collected a total of 85 streambed sediment samples from 8 sites in conjunction with the collection of water-quality samples in the mining district from 2004-2006. Those sediment samples were collected from the same locations during each sampling period by using decontaminated plastic spoons and bowls. No sieving, nor any other sediment-size-separation techniques, was done with these samples prior to digestion and analysis. Those sediment samples were analyzed by the USGS NWQL for metals concentrations by using microwave-assisted acid digestion (U.S. Environmental Protection Agency, 1998) and analysis of digestate fluids by inductively coupled plasma-optical emission spectrometry and inductively coupled plasma-mass spectrometry (Garbarino and Struzeski, 1998).

\section{Water-Quality Sampling and Analyses}

Streamflow measurements were made coincident with collection of about half of the surface-water-quality samples, those samples collected at high-flow conditions. Streamflow measurements associated with those samples were made by using either acoustic Doppler velocity (ADV) instruments, Doppler profilers (ADCP), or with Price AA or pygmy current meters in accordance with protocols described in Rantz and others (1982) and Oberg and others (2005). Sampling times and stream discharge measurements were not recorded in conjunction with collection of surface-water-quality samples at low- flow conditions. As a result, three approaches, described in tables 5 and 6 , were used to discard water-quality data or to estimate stream discharge at the times of collection of those samples.

Surface-water-quality samples were collected and water properties such as $\mathrm{pH}$, temperature, turbidity, and dissolved oxygen concentrations were collected and measured according to protocols described by Wilde and others (1998a and b). Water samples collected from 2000 through 2003 were analyzed by the NWQL for concentrations of total and dissolved metals (aluminum, cadmium, iron, lead, manganese, and zinc) by inductively coupled plasma (ICP) method (Faires, 1993). 


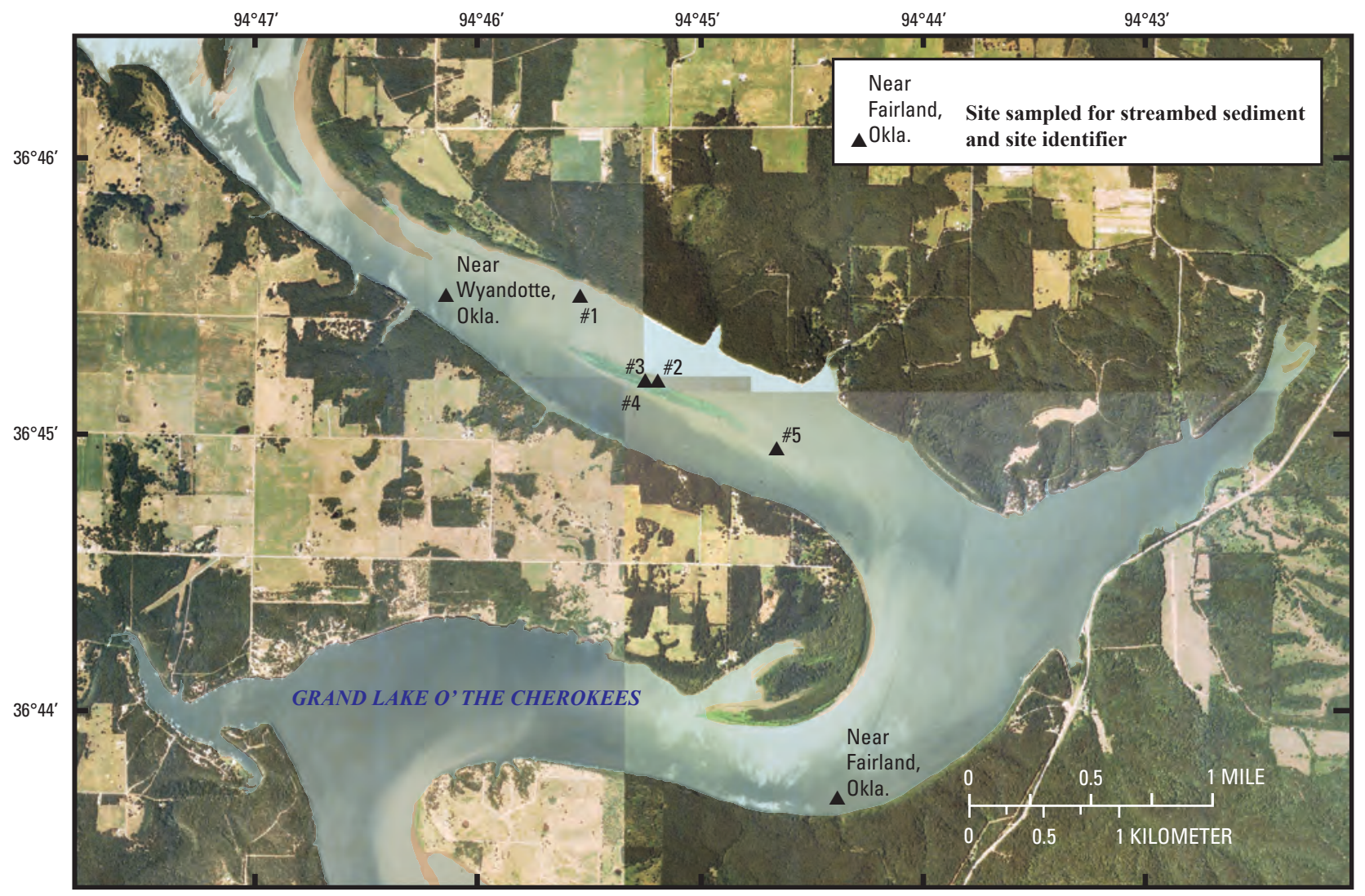

Aerial photo mosaic from

U.S. Department of Agriculture (2003)

Universal Transverse Mercator,

Zone 15N Projection

North American Datum 1983

Figure 4. Location of sites sampled for sediments in the upstream part of Grand Lake 0' the Cherokees, April 2002 and April 2004.
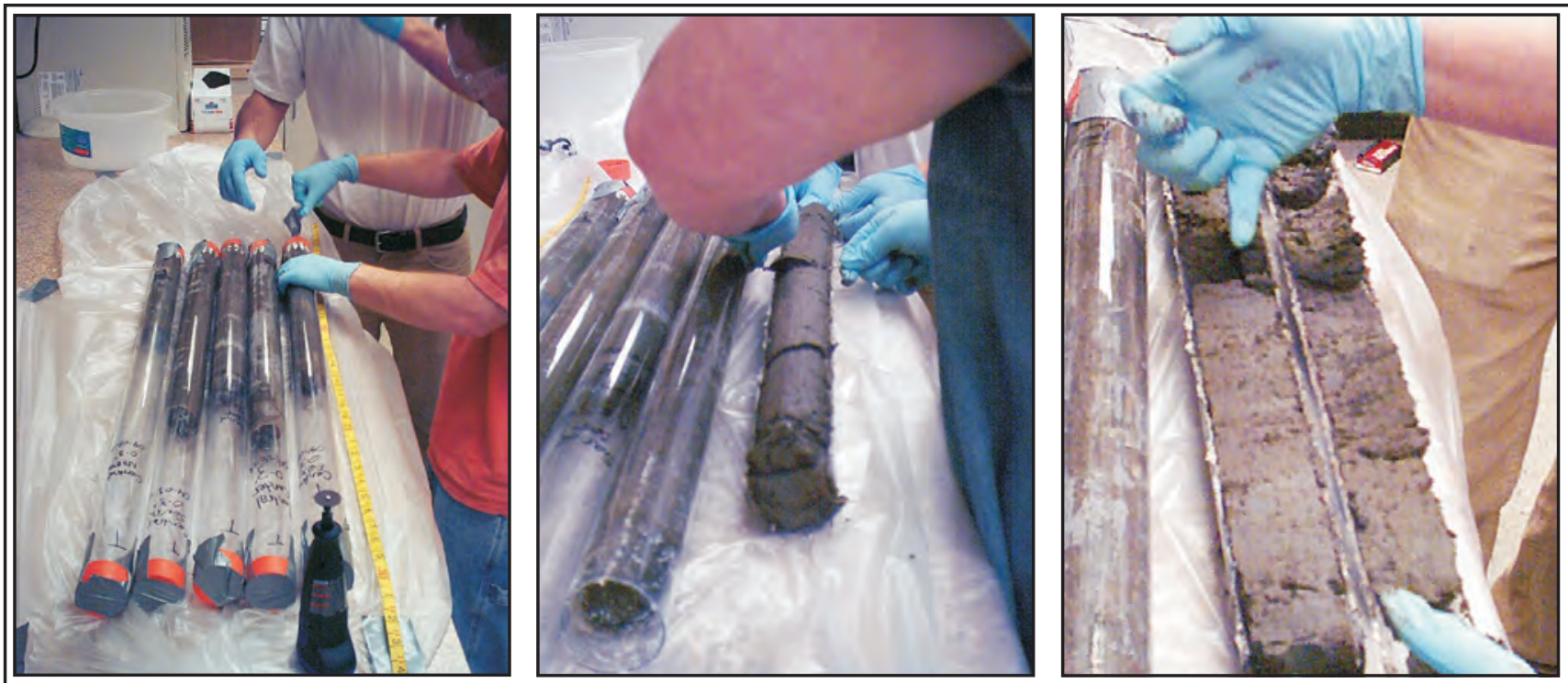

Figure 5. Measurement and processing of sediment cores collected in the upstream end of Grand Lake 0' the Cherokees in April 2004. 


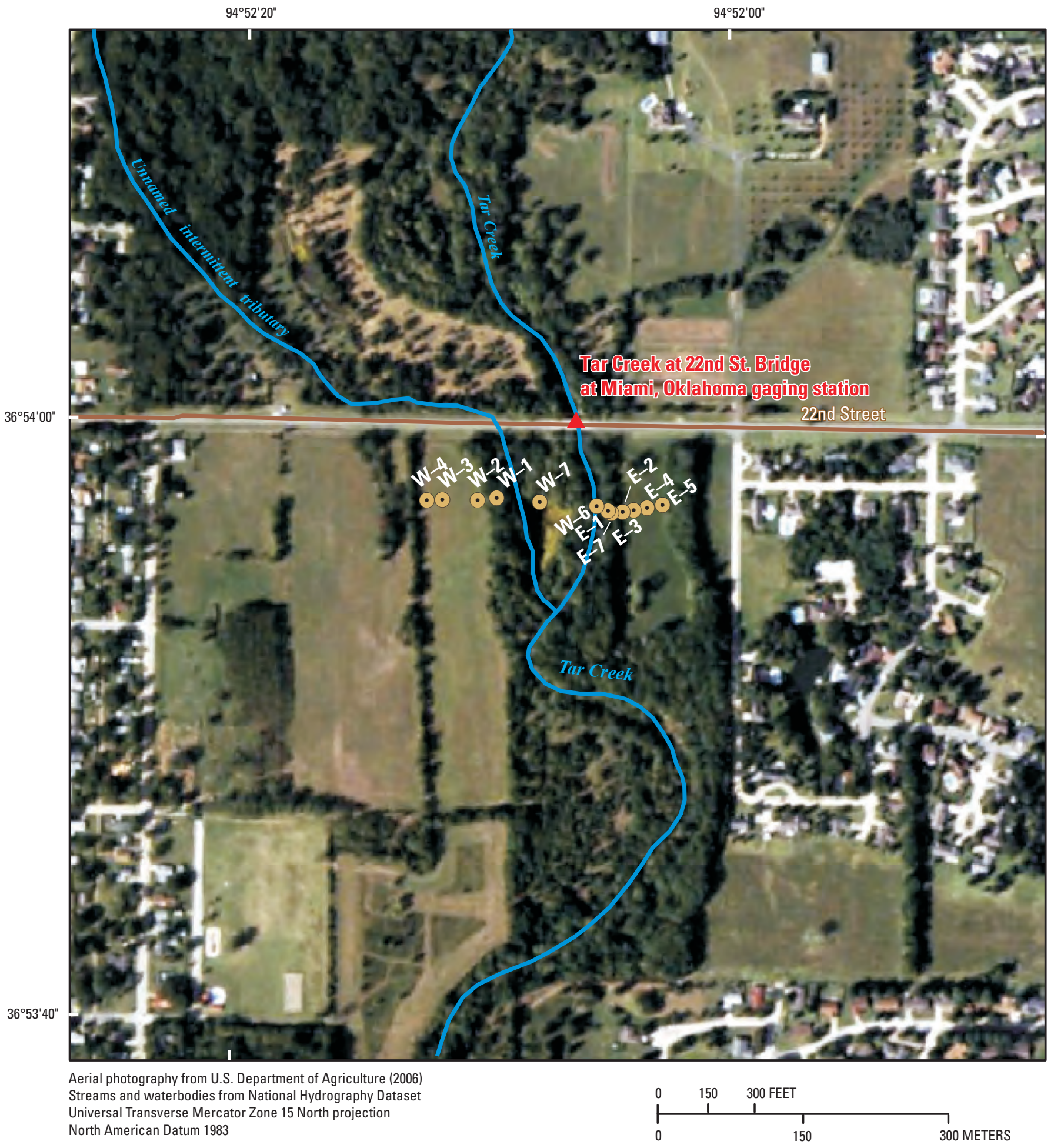

EXPLANATION

$\odot$ Sediment core

Figure 6. Locations of sediment cores collected on the floodplain of Tar Creek south of the 22nd Street Bridge in Miami, Oklahoma, on June 16, 2004. 
Table 4. Locations and depths of floodplain sediment cores collected along a transect near Tar Creek at the 22nd Street Bridge at Miami, Oklahoma gaging station on June 16, 2004.

[all latitudes and longitudes are referenced to the North American Datum 83 geographic datum]

\begin{tabular}{|c|c|c|c|}
\hline Site identifier & $\begin{array}{l}\text { U.S. Geological } \\
\text { Survey site } \\
\text { identification number }\end{array}$ & $\begin{array}{c}\text { Site latitudes and } \\
\text { Iongitudes, in decimal } \\
\text { degrees }\end{array}$ & $\begin{array}{c}\text { Ranges of depths } \\
\text { of core } \\
\text { subsamples, in feet } \\
\text { below land surface }\end{array}$ \\
\hline E1 & 365357094520402 & $\begin{array}{c}\text { N36.89921, } \\
\text { W-094.86786 }\end{array}$ & $\begin{array}{c}0-0.20 \\
0.20-1.50 \\
1.50-3.00\end{array}$ \\
\hline E2 & 365357094520401 & $\begin{array}{c}\text { N36.89922, } \\
\text { W-094.86773 }\end{array}$ & $\begin{array}{c}0-0.15, \\
0.15-1.10 \\
1.10-2.90\end{array}$ \\
\hline E3 & 365357094520302 & $\begin{array}{c}\text { N36.89924, } \\
\text { W-094.86760 }\end{array}$ & $\begin{array}{c}0-0.10 \\
0.10-0.80 \\
0.80-2.70\end{array}$ \\
\hline E4 & 365357094520301 & $\begin{array}{c}\text { N36.89926, } \\
\text { W-094.86745 }\end{array}$ & $\begin{array}{c}0-0.10 \\
0.10-1.00 \\
1.00-2.10\end{array}$ \\
\hline E5 & 365357094520201 & $\begin{array}{c}\text { N36.89929, } \\
\text { W-094.86727 }\end{array}$ & $\begin{array}{c}0-0.10 \\
0.10-1.60 \\
1.60-2.60\end{array}$ \\
\hline E7 & 365357094520403 & $\begin{array}{c}\text { N36.89923, } \\
\text { W-094.86790 }\end{array}$ & $0-1.00$ \\
\hline W1 & 365358094520901 & $\begin{array}{c}\text { N36.89933, } \\
\text { W-094.86919 }\end{array}$ & $\begin{array}{c}0-0.15 \\
0.15-1.50 \\
1.50-2.60\end{array}$ \\
\hline W2 & 365358094521002 & $\begin{array}{c}\text { N36.89930, } \\
\text { W-094.86941 }\end{array}$ & $\begin{array}{c}0-0.20 \\
0.20-1.40 \\
1.40-3.50\end{array}$ \\
\hline W3 & 365358094521101 & $\begin{array}{c}\text { N36.89930, } \\
\text { W-094.86982 }\end{array}$ & $\begin{array}{c}0-0.20 \\
0.20-1.20 \\
1.20-3.40\end{array}$ \\
\hline W4 & 365357094521201 & $\begin{array}{c}\text { N36.89929, } \\
\text { W-094.87000 }\end{array}$ & $\begin{array}{c}0-0.15 \\
0.15-1.00 \\
1.00-3.00\end{array}$ \\
\hline W6 & 365357094520501 & $\begin{array}{c}\text { N36.89927, } \\
\text { W-094.86803 }\end{array}$ & $\begin{array}{c}0-0.90 \\
0.90-1.35\end{array}$ \\
\hline W7 & 365357094520701 & $\begin{array}{c}\text { N36.89930, } \\
\text { W-094.86869 }\end{array}$ & $\begin{array}{c}0-0.90 \\
0.90-1.70\end{array}$ \\
\hline
\end{tabular}


Table 5. Stream sites sampled for water quality and streambed sediment in the Oklahoma part of the Tri-State mining district, 2000-06.

[sites listed in downstream order; NAD, North American Datum; under low-flow sample data included column, 1 indicates streamflow measurements made for all samples collected, 2 indicates data not included in report, as streamflows could not be reliably estimated; 3 indicates mean daily streamflow at gage used to estimate streamflow at time of sampling, 4 indicates streamflows at low-flow conditions were estimated by linear regressions between mean daily streamflows at upstream gaging stations at Spring River near Quapaw, Oklahoma or Neosho River near Commerce Oklahoma gages and streamflows measured at higher-flow conditions at sampling times for those sites; 5 indicates that streamflow measurements could not be made due to backwater (no-flow) conditions]

\begin{tabular}{|c|c|c|c|c|c|}
\hline Site name & $\begin{array}{l}\text { U.S. Geological } \\
\text { Survey site } \\
\text { identification } \\
\text { number }\end{array}$ & $\begin{array}{l}\text { Latitude, and } \\
\text { longitude, } \\
\text { in decimal } \\
\text { degrees }\end{array}$ & $\begin{array}{l}\text { Latitude } \\
\text { and } \\
\text { Iongitude } \\
\text { datum }\end{array}$ & $\begin{array}{l}\text { Sampled for } \\
\text { streambed } \\
\text { sediment }\end{array}$ & $\begin{array}{l}\text { Low-flow } \\
\text { sample data } \\
\text { included }\end{array}$ \\
\hline Neosho River near Commerce, Oklahoma & 07185000 & $\begin{array}{l}\text { N36.929, } \\
\text { W-094.957 }\end{array}$ & NAD83 & Yes & 3 \\
\hline Neosho River near Wyandotte, Oklahoma & 07185190 & $\begin{array}{l}\text { N36.797, } \\
\text { W-094.754 }\end{array}$ & NAD83 & Yes & 4 \\
\hline Elm Creek at Commerce, Oklahoma & 071850850 & $\begin{array}{l}\text { N36.944, } \\
\text { W-094.905 }\end{array}$ & NAD83 & No & 1 \\
\hline $\begin{array}{l}\text { Lytle Creek at State Line Road } \\
\text { near Picher, Oklahoma }\end{array}$ & 071850840 & $\begin{array}{l}\text { N36.999, } \\
\text { W-094.801 }\end{array}$ & NAD83 & No & 1 \\
\hline Lytle Creek near Cardin, Oklahoma & 071850870 & $\begin{array}{l}\text { N36.962, } \\
\text { W-094.846 }\end{array}$ & NAD83 & No & 2 \\
\hline $\begin{array}{l}\text { Tar Creek Tributary at Western Chat Pile } \\
\text { at Cardin, Oklahoma }\end{array}$ & 071850818 & $\begin{array}{l}\text { N36.978, } \\
\text { W-094.852 }\end{array}$ & NAD83 & No & 1 \\
\hline Tar Creek near Cardin, Oklahoma & 071850825 & $\begin{array}{l}\text { N36.963, } \\
\text { W-094.846 }\end{array}$ & NAD83 & No & 1 \\
\hline $\begin{array}{l}\text { Tar Creek above Douthat Bridge } \\
\text { near Cardin, Oklahoma }\end{array}$ & 071850875 & $\begin{array}{l}\text { N36.959, } \\
\mathrm{W}-094.845\end{array}$ & NAD83 & No & 2 \\
\hline Tar Creek near Picher, Oklahoma & 07185088 & $\begin{array}{l}\text { N36.958, } \\
\text { W-094.846 }\end{array}$ & NAD83 & No & 2 \\
\hline Tar Creek near Commerce, Oklahoma & 07185090 & $\begin{array}{l}\text { N36.944, } \\
\text { W-094.853 }\end{array}$ & NAD83 & Yes & 3 \\
\hline $\begin{array}{l}\text { Tar Creek at 22nd Street Bridge at Miami, } \\
\text { Oklahoma }\end{array}$ & 07185095 & $\begin{array}{l}\text { N36.900, } \\
\text { W-094.868 }\end{array}$ & NAD83 & Yes & 3 \\
\hline $\begin{array}{l}\text { Spring River above Devils Hollow } \\
\text { near Quapaw, Oklahoma }\end{array}$ & 07187995 & $\begin{array}{l}\text { N36.961, } \\
\mathrm{W}-094.721\end{array}$ & NAD83 & No & 1 \\
\hline Spring River near Quapaw, Oklahoma & 07188000 & $\begin{array}{l}\text { N36.934, } \\
\text { W-094.747 }\end{array}$ & NAD83 & Yes & 3 \\
\hline Spring River near Wyandotte, Oklahoma & 07188180 & $\begin{array}{l}\text { N36.801, } \\
\mathrm{W}-094.753\end{array}$ & NAD83 & Yes & 4 \\
\hline Beaver Creek near Quapaw, Oklahoma & 07188005 & $\begin{array}{l}\text { N36.934, } \\
\text { W-094.754 }\end{array}$ & NAD83 & No & 1 \\
\hline $\begin{array}{l}\text { Beaver Creek above Spring River } \\
\text { near Quapaw, Oklahoma }\end{array}$ & 07880070 & $\begin{array}{l}\text { N36.932, } \\
\mathrm{W}-094.751\end{array}$ & NAD83 & No & 1 \\
\hline $\begin{array}{l}\text { Grand Lake O' the Cherokees } \\
\text { near Wyandotte, Oklahoma }\end{array}$ & 364532094460801 & $\begin{array}{l}\text { N36.759, } \\
\mathrm{W}-094.769\end{array}$ & NAD27 & Yes & 5 \\
\hline $\begin{array}{l}\text { Grand Lake O' the Cherokees } \\
\text { near Fairland, Oklahoma }\end{array}$ & 364344094442001 & $\begin{array}{l}\text { N36.729, } \\
\text { W-094.739 }\end{array}$ & NAD27 & Yes & 5 \\
\hline
\end{tabular}


Table 6. Regression equations used to estimate streamflow at time of water-quality sampling at selected stream sites in the Oklahoma portion of the Tri-State mining district, 2000-06.

\begin{tabular}{llll}
\hline $\begin{array}{c}\text { Upstream station with } \\
\text { known mean daily } \\
\text { streamflow }\end{array}$ & $\begin{array}{c}\text { Station with estimated } \\
\text { streamflow at time } \\
\text { of sampling }\end{array}$ & Regression equation & $\begin{array}{c}\mathbf{r}^{2} \text { correlation } \\
\text { coefficient }\end{array}$ \\
\hline $\begin{array}{l}\text { Spring River near } \\
\text { Quapaw, Oklahoma }\end{array}$ & $\begin{array}{l}\text { Spring River near } \\
\text { Wyandotte, Oklahoma }\end{array}$ & Estimated streamflow $=(0.691$ *known upstream flow $) 1.039$ \\
$\begin{array}{l}\text { Neosho River near } \\
\text { Commerce, Oklahoma }\end{array}$ & $\begin{array}{l}\text { Neosho River near } \\
\text { Wyandotte, Oklahoma }\end{array}$ & Estimated streamflow $=(0.591$ *known upstreamflow $) 1.057$ & 0.976 \\
\hline
\end{tabular}

Surface-water-quality samples collected from 2004 through 2006 were block digested and analyzed by inductivelycoupled plasma-atomic emission spectrometry with Thermo Jerrell Ash Trace ICP Analyzer at the DEQ Laboratory in Oklahoma City, Oklahoma, by using methods described in U.S. Environmental Protection Agency (EPA) Method 200.7 (Martin and others, 1994).

\section{Quality Assurance and Quality Control}

Several quality-assurance samples were collected and analyzed to investigate the possibility of equipment contamination and natural sample variability. The 216 field waterquality samples were accompanied by 19 field blanks ( 8.8 percent frequency), 28 field duplicates (13.0 percent frequency), and 7 equipment blanks ( 3.2 percent frequency). Total zinc was detected in one blank at a concentration of 25 micrograms per liter $(\mu \mathrm{g} / \mathrm{L})$, which was greater than the minimum reporting level of $5 \mu \mathrm{g} / \mathrm{L}$. Total and dissolved zinc were detected at concentrations of $7 \mu \mathrm{g} / \mathrm{L}$ in one equipment blank. No blank samples were collected for the 89 streambed-sediment samples collected in conjunction with water-quality sampling or with the sediment cores collected on the sand bar at the upstream end of Grand Lake O' the Cherokees and in the floodplain of Tar Creek at Miami, Oklahoma. However, 13 duplicate sediment samples were collected in conjunction with those 89 samples (14.6 percent collection frequency).

Relative percent differences for metals concentrations in streambed-sediment samples typically were 20 percent or more (fig. 7). Relative percent differences between fieldduplicate water-quality samples generally were less than 10 percent, indicating good consistency of water-quality and other sampling variables at the times of sampling (fig. 7). Greater relative percent differences for sediment samples than for water samples probably were a result of greater heterogeneity of metals content of streambed sediments than in the well-mixed stream water.

\section{Data Analysis}

Metals concentration, streamflow, and metals-load data were graphed by using S-Plus, version 7.0, statistical software (Insightful Corporation, 2005). Censored data concentrations were estimated by substitution of values of half of the minimum reporting levels for evaluating relations between concentrations and streamflow. The maximum likelihood estimation (MLE) method (Cohen, 1959) was used for constructing boxplots of concentrations and estimating metals loads in censored data sets.

\section{Selected Metals in Streambed Sediments}

The primary metals associated with sulfide ores in the mines were cadmium, iron, lead, and zinc (McKnight and Fischer, 1970). Concentrations of those metals, and of aluminum and manganese, range from the tens to tens of thousands of milligrams per kilogram in local tailings, which are sources of part of the metals in local streams (table 1, Datin and Cates, 2002; Schaider and others, 2007). Sediments were sampled in different settings in and downstream from the mining district to determine how metals may have been transported from mining areas to adjoining streams.

\section{Lakebed Sediments}

Grand Lake O' the Cherokees (fig. 3) ultimately receives the surface-water drainage from the mining district. Sampling of sediments at two sites in the Neosho River in the upstream end of Grand Lake O' the Cherokees in April 2002 and April 2004 (table 3, figs. 3 and 4) indicated that concentrations of zinc, the primary metal mined in the district, range from about 400 to $600 \mathrm{mg} / \mathrm{Kg}$; whereas lead concentrations were less than $50 \mathrm{mg} / \mathrm{Kg}$ (fig. 8a). 


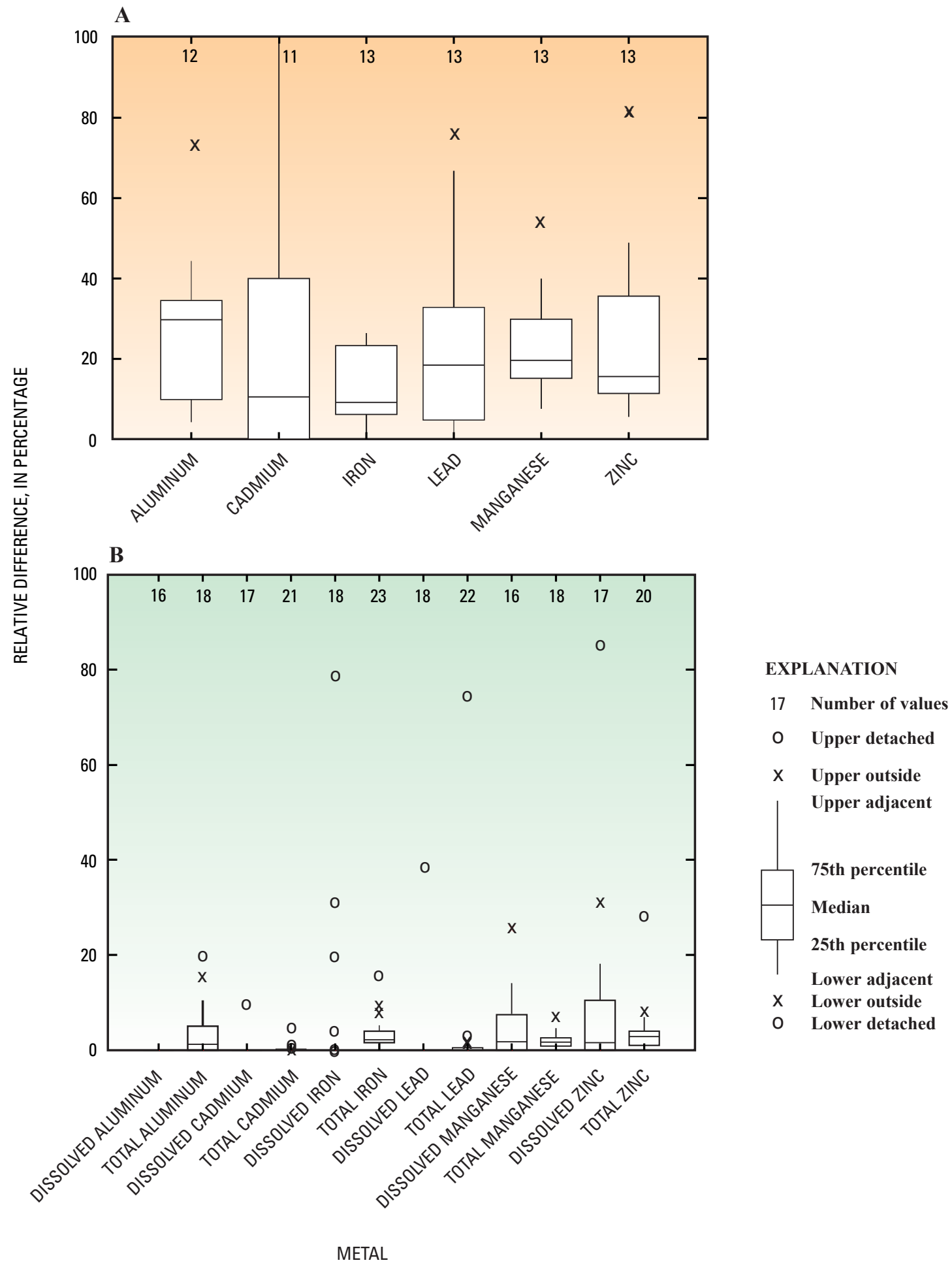

Figure 7. Relative percent differences for concentrations of (A) selected metals in streambed sediment, and (B) water duplicate samples collected in the Oklahoma part of the Tri-State mining district, 2000-06. 
Sampling of five sites on a mid-channel sand bar for additional metals in April 2004 (table 3, figs. 3 and 4) indicated that sediment samples in the upstream end of the lake can contain several thousand milligrams per kilogram of aluminum and iron, and several hundred milligrams per kilogram of manganese and zinc (figs. $8 \mathrm{~b}$ and $8 \mathrm{c}$ ). Lead concentrations were about 10 percent of the concentrations of zinc and cadmium concentrations were about 0.1 percent of zinc concentrations, which is consistent with ratios of those metals in tailings in the district (table 1, Datin and Cates, 2002; Schaider and others, 2007). No clear trends were detected in total cadmium, lead, and zinc concentrations in the sediments in downstream direction (north to south, sites 1 to 5 , figs. 4 and 8 ) on that sand bar.

\section{Floodplain Sediments}

A transect of sediment cores collected across the floodplain of Tar Creek near Miami, Oklahoma, in 2004 were similar to or greater than concentrations of those metals in the upstream end of Grand Lake O' the Cherokees. Concentrations of cadmium, lead, and zinc in sediment samples from a transect of cores collected on June 16, 2004, on the floodplain of Tar Creek about 165 feet south of the 22nd Street Bridge in Miami, Oklahoma, (figs. 3, 6, and 9) generally were greatest at cores W6 and W7 (fig. 9) that correspond to the location of a slough, which is the channel of an intermittent creek flowing from mined areas in Commerce, Oklahoma, southeastward toward Miami, Oklahoma. Metals concentrations in sediments near that slough were similar or greater than were reported for streambed sediment at nearby sites on Tar Creek in the mid-1980s (Parkhurst and others, 1988) and were similar to concentrations of cadmium, iron, lead and zinc in tailings (fig. 8, table 1, Datin and Cates, 2002; Schaider and others, 2007). Sediment-size analyses were not done on those samples, but visual observation of the cores indicated interbedded fine sands, silty sands, and silty clays (fig. 5). The slough area near the center of the transect tended to have finer sediments than the cores collected on the western and eastern end of the transect (Caleb Cope, U.S. Geological Survey, written commun., 2004), with finer sediments commonly being associated with greater metals concentrations in tailings in the mining district (table 1).

Large concentrations of aluminum and manganese may be indigenous to local soils in the forms of clay minerals and manganese oxide concretions. Concentrations of these two metals had different patterns than the other metals in the cores (fig. 9). The greatest concentrations of aluminum were in samples from the westernmost core (W-4) and core E-4, east of Tar Creek (fig. 9). The greatest concentrations of manganese were 1.5 to 2.0 feet below land surface in the cores closest to Tar Creek (fig. 9). Concentrations of both of these metals were greater in these cores than in local tailings

(fig. 9, table 1, Datin and Cates, 2002; Schaider and others, 2007). General increases in aluminum and manganese with depth (fig. 9) may be a result of leaching of these metals from shallow soil layers and/or to greater concentrations of these metals in less-weathered subsoils and shales with depth.

\section{Streambed Sediments}

Streambed sediments collected from Tar Creek at the 22nd Street Bridge in Miami, Oklahoma, gaging station from 2004 through 2006 had similar ranges of metals concentrations as those ranges recorded in the sediment cores collected in the floodplain of Tar Creek on June 16, 2004 (figs. 9 and 10). The greatest metal concentrations in local sediments may be associated with tailings and ground water seeping from the mines, but also may have sources in the mineral components of local soils and bedrock, such as aluminum (associated with clays), and iron and manganese (associated with oxidized soils or local shales) (Hem, 1992, p. 73; Drever, 1988, p. 342).

\section{Aluminum}

Aluminum concentrations in streambed sediments increased in the downstream direction on the Neosho River, Tar Creek, and the Spring River, possibly because of runoff of aluminum in clays in local soils and tailings (fig. 10 and table 1). The greatest aluminum concentrations generally were in streambed sediments at the two sampled sites on the Neosho River (fig. 10), the drainage basin of which is largely underlain by Krebs Group shales of Mississippian age (McKnight and Fischer, 1970), a probable source of clay minerals containing aluminum.

\section{Cadmium}

Cadmium was not detected in streambed sediments at the Neosho River near the Wyandotte, Oklahoma, site. Sorption to iron oxide and hydroxide in upstream sediments, small concentrations of cadmium in tailings (table 1), or the high propensity of cadmium to dissolve, rather than precipitate (Carroll and others, 1998; O'Day and others, 1998; Morel and Hering, 1993, p. 355), may account for the lack of detectable cadmium in streambed sediments several miles downstream from the mining district. Cadmium concentrations decreased in the downstream direction in Tar Creek (fig. 10). Those concentration decreases were probably a result of some combination of dilution of cadmium with other sediments, dissolution and/or flushing of cadmium into the water column, or sequestration of cadmium in upstream sediments. Greater cadmium concentrations in streambed sediments in the downstream direction, such as those concentrations in the Spring River, may be a result of flushing of older, more cadmium-enriched sediments downstream or inputs of additional sources of cadmium-containing sediments between the sites near Quapaw and Wyandotte, Oklahoma (fig. 10). 
Streambed sediment samples collected in the upstream end A of Grand Lake O' the Cherokees, April 2002 and April 2004

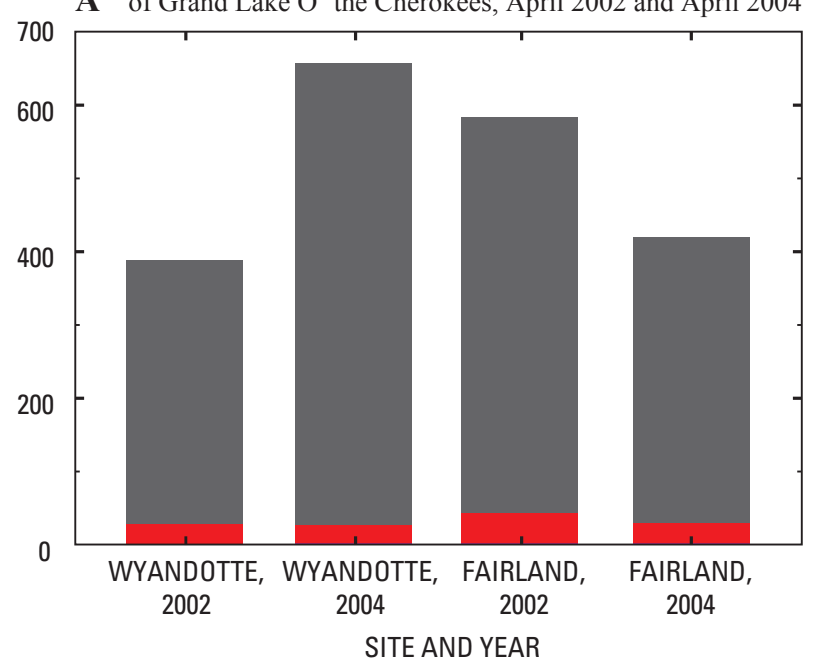

Streambed sediment samples collected on a sandbar in the

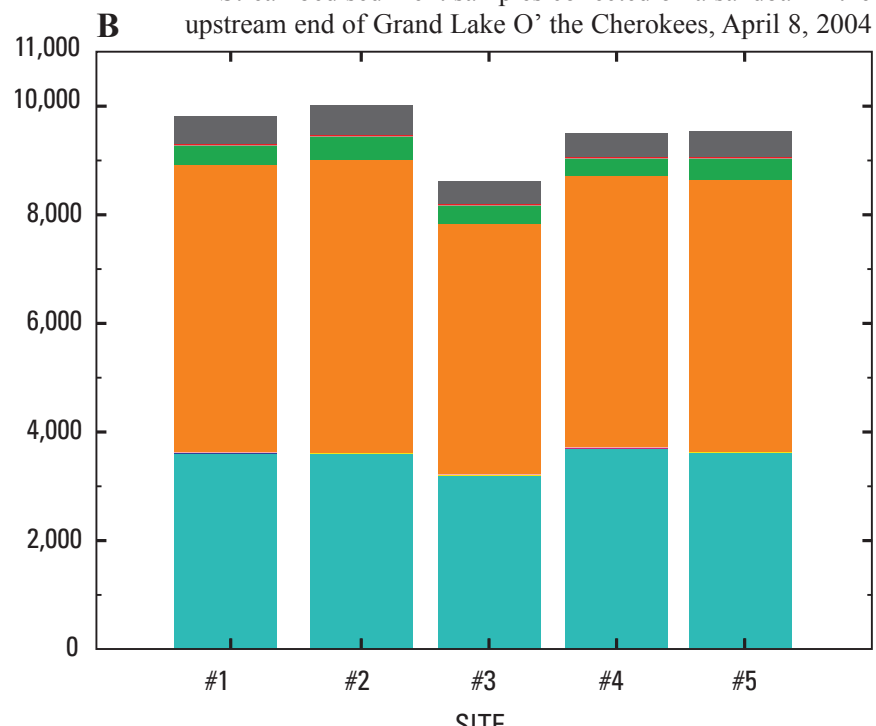

Streambed sediment samples collected on a sandbar in the

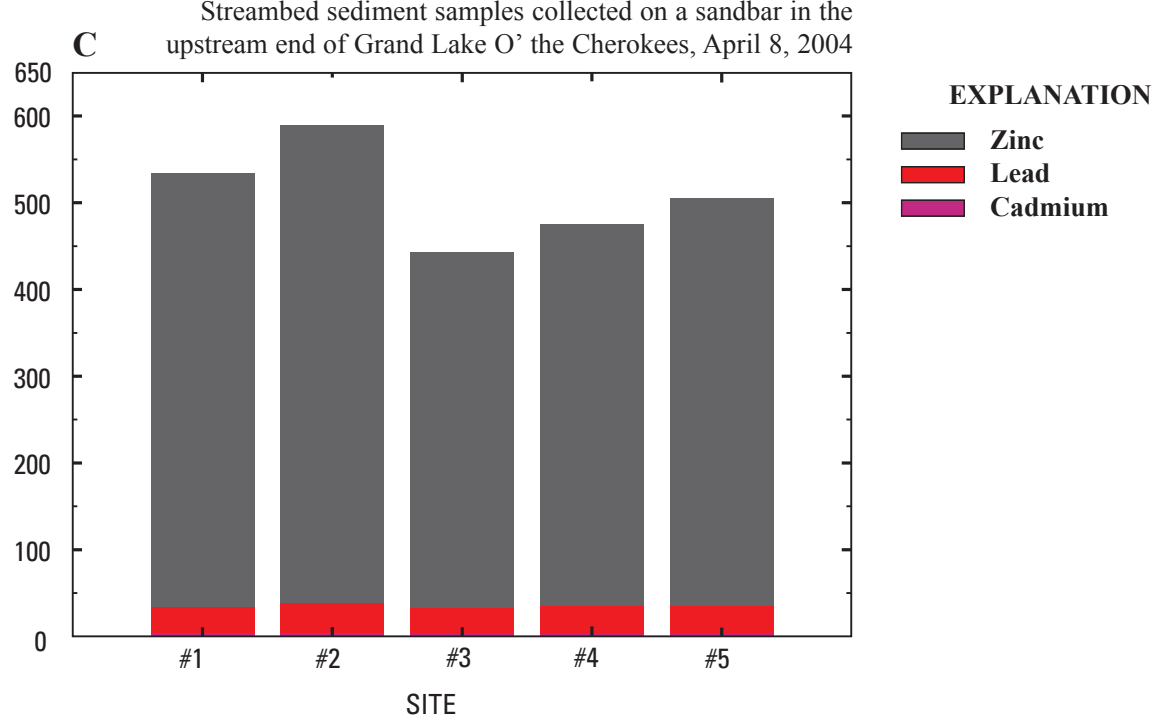

Figure 8. Selected metals

EXPLANATION Zinc Lead Nickel Manganese Iron Aluminum concentrations in streambed samples collected at sites in the upstream end of Grand Lake 0 ' the Cherokees, April 2002 and April 2004. 


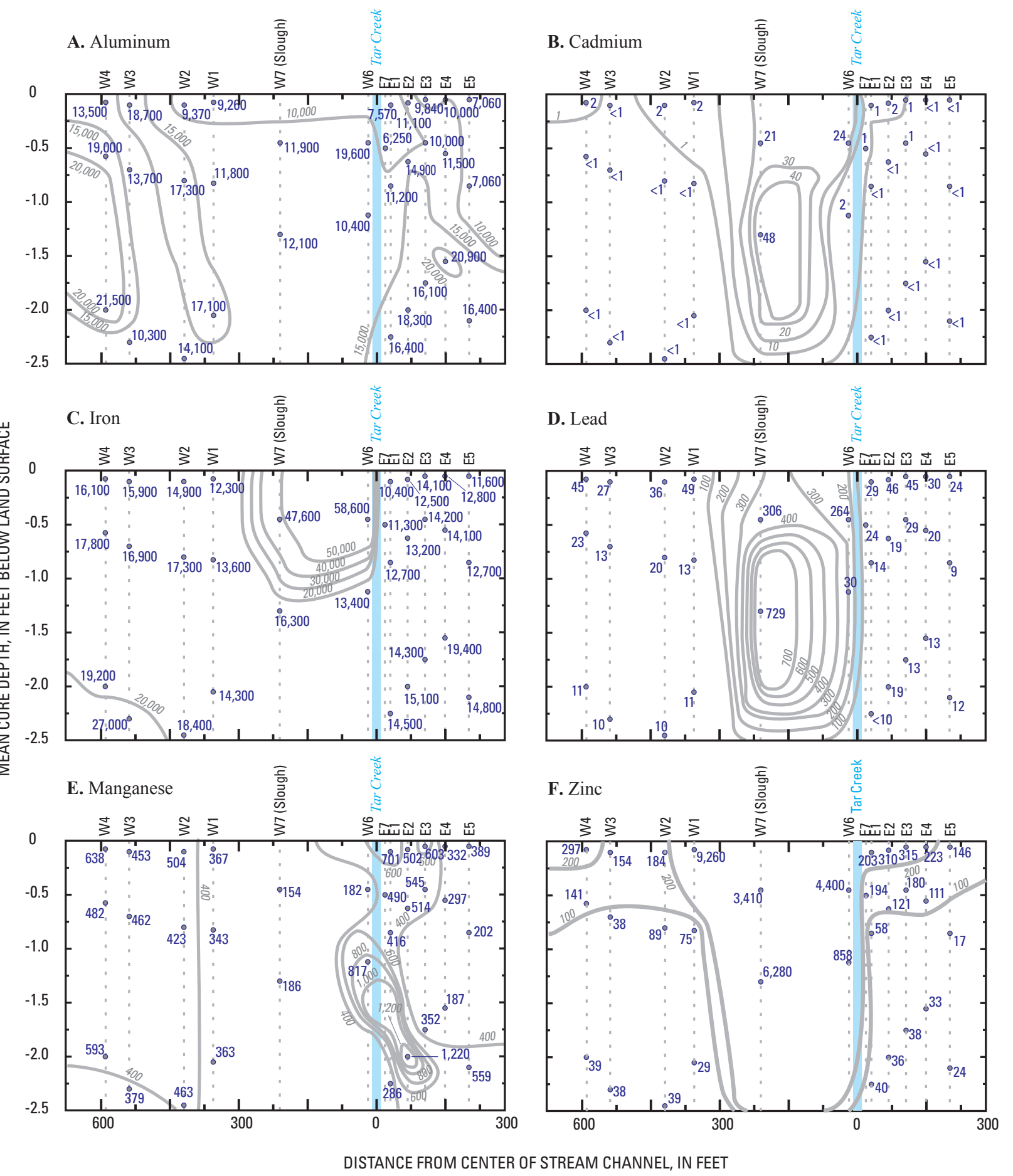

EXPLANATION

\footnotetext{
- 1,000 — Line of equal value-Intervals variable

490 Sample location and value in milligrams per kilogram $-<$, less than

E5 Sample identifier
}

Figure 9. Cross-sectional diagrams showing distributions of concentrations of (A) aluminum, (B) cadmium, (C) iron, (D) lead, (E) manganese, and (F) zinc in sediment cores collected in a transect 165 feet south of the 22nd Street Bridge at Tar Creek at Miami, Oklahoma, on June 16, 2004. 

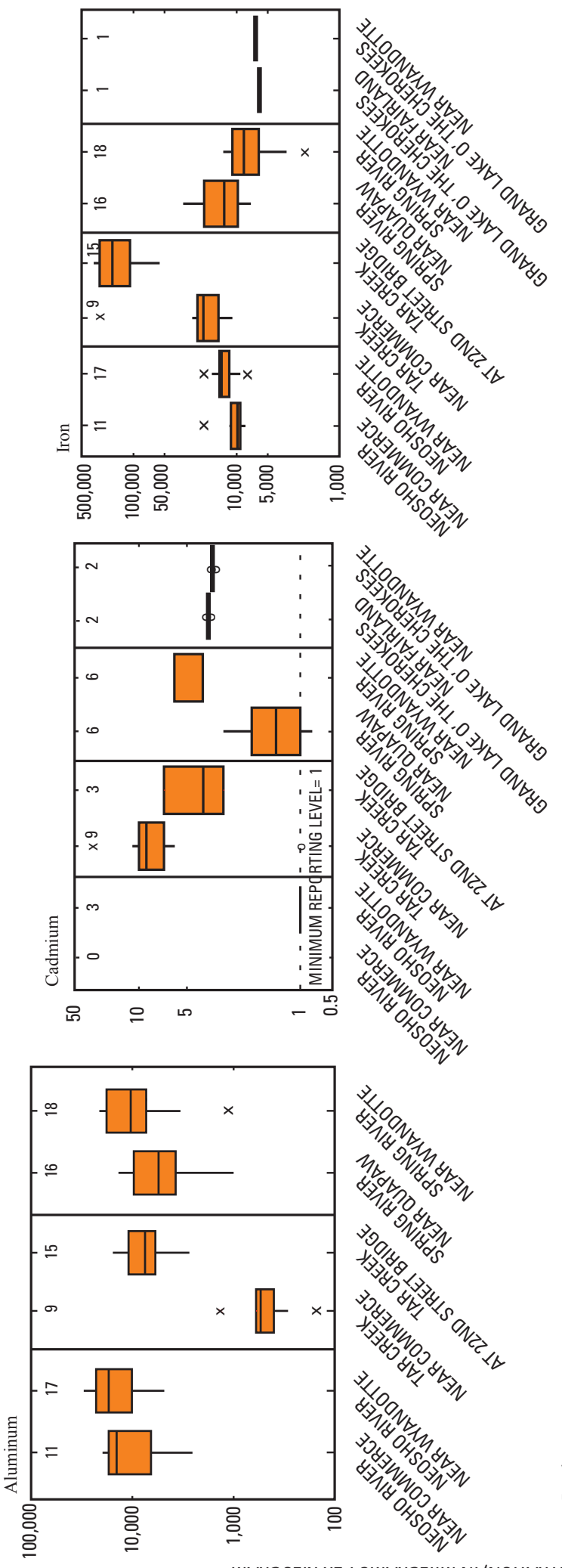
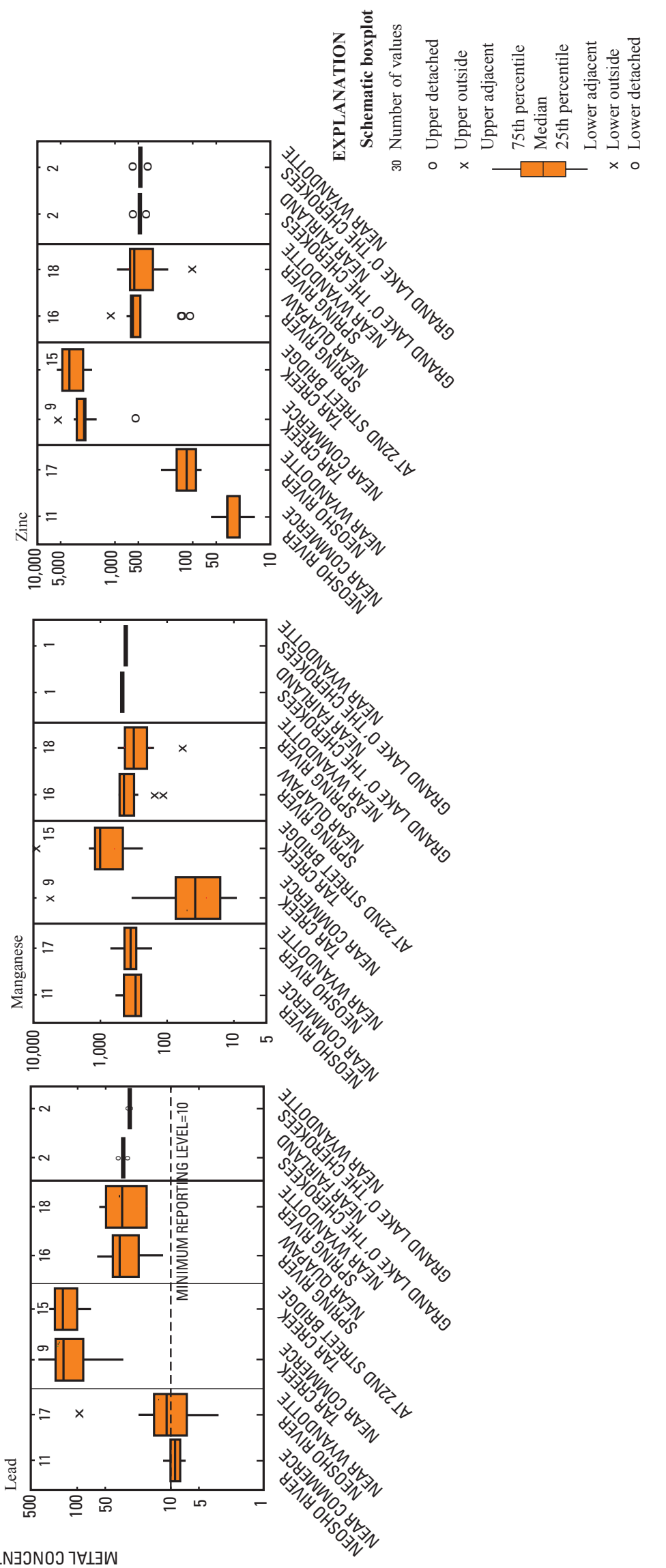

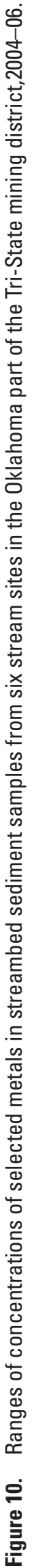


Iron

Iron, which tends to precipitate as oxide and hydroxide minerals in the alkaline and oxidizing conditions of local streams (fig. 11, Elder, 1988, p. 11 and 15), generally occurred in the greatest concentrations of the analyzed metals in streambed sediments (figs. 2 and 10, Morel and Hering, 1993, p. 267-271; Hem, 1992, p. 79-80; Drever, 1988, p. 297; and Stumm and Morgan, 1981, p. 241). Although oxidation of tens of thousands of micrograms per liter of iron likely happens rapidly, producing acid in addition to the acid produced by sulfide dissolution in the mine workings (equation 1), abundant carbonate minerals such as calcite and dolomite in local rocks buffer those acids (equation 2), and bring $\mathrm{pH}$ of ground water in the mines and local surface water up to circum-neutral values of 6 or more (DeHay, 2003; DeHay and others, 2004; and fig. 11). Real-time monitors, recording water-quality data at 15-minute intervals, at the Tar Creek at Commerce, Oklahoma, Tar Creek at 22nd Street Bridge in Miami, Oklahoma, and the Beaver Creek near Quapaw, Oklahoma, sites from 2004 to 2006 obtained similar ranges of $\mathrm{pH}$ and dissolved oxygen concentrations (fig. 11).

$2 \mathrm{Fe}^{+2}$ (dissolved) $+2 \mathrm{H}_{2} \mathrm{O}+\mathrm{O}_{2} \rightarrow 2 \mathrm{FeOOH}$ (solid goethite) $+2 \mathrm{H}^{+}$

$\mathrm{CaCO}_{3}$ (solid calcite) $+\mathrm{H}^{+} \rightarrow \mathrm{Ca}^{+2}$ (dissolved) $+\mathrm{HCO}_{3}^{-}$(dissolved bicarbonate)

Iron concentrations in sediments increased in the downstream direction for the two sites sampled on the Neosho River and Tar Creek, but decreased in the downstream direction between the two sites sampled on the Spring River

(fig. 10). Increased iron concentration in streambed sediments in the downstream direction in the Neosho River and Tar Creek may be a result of a combination of runoff and seepage from tailings and/or the mine workings, and runoff of ferruginous soil particles from sources in the downstream direction. Decreased iron concentration in streambed sediments in the downstream direction at the two Spring River sites may be a result of flushing of soft flocculated iron particles farther downstream or to trapping of ferruginous minerals in parts of the river upstream from the site near Wyandotte, Oklahoma. In addition to being the dominant precipitated metal in local streams, ferric oxyhydroxide surfaces also can adsorb other metals, with greater absorption taking place at higher $\mathrm{pH}$ (Hem, 1992, p. 78; Drever, 1988, p. 343).

\section{Lead}

Lead concentrations are likely to be much greater in streambed sediments than in water because lead has: (a) small solubility constants in sulfide and hydroxycarbonate minerals, (b) tendency to precipitate with manganese oxide, and (c) tendency to adsorb to organic and inorganic sediment surfaces (American Water Works Research Association
Foundation, 1996, p. 140; Morel and Herring, 1993, p. 524; Hem, 1992, p. 143; Drever, 1988, p. 344; Stumm and Morgan, 1981, p. 243 and 245). Lead was detected in concentrations about only one order of magnitude (10 times) greater than cadmium in streambed sediments, despite being found in concentrations 30-100 times greater than cadmium in tailings (table 1 and fig. 10). The relative scarcity of lead compared to cadmium in local streambed sediments may be a result of adsorption of lead to mobile organic and clay particles in stream water that have been flushed downstream, or to seepage of dissolved cadmium from oxidizing sphalerite $(\mathrm{ZnS})$ in local mine workings. The relative similarity of lead concentrations in streambed sediments at the sampled sites (fig. 10) indicated a mechanism such as adsorption of lead to and transport on organic and inorganic sediment particles that resulted in even distribution in streambed sediments.

\section{Manganese}

Manganese can substitute for iron, magnesium, or calcium in silicate minerals and participates in reactions similar to reactions of iron in similar redox conditions, but manganese is slightly less likely to oxidize and precipitate than iron and has extremely high adsorption capacities for heavy metals (Morel and Hering, 1993, p. 243-244, Hem, 1992, p. 85, Drever, 1988, p. 342). Similar to iron, manganese concentrations increased in the downstream direction for the sites sampled on the Neosho River and Tar Creek, and decreased in the downstream direction for the two sites sampled on the Spring River (fig. 10).

\section{Zinc}

Concentrations of zinc, the metal extracted in the greatest amounts from this mining district, were at least an order of magnitude or more greater than lead concentrations and 50 times or more greater than cadmium concentrations in the streambed-sediment samples (fig. 10). After zinc dissolves from sphalerite in the mine workings and in tailings, zinc combines with oxygen, hydroxide, and carbonate to form a variety of precipitating minerals and is sequestered with iron oxyhydroxide minerals on the land surface and in local streams (Carroll and others, 1998; O'Day and others, 1998). Similar to iron, zinc concentrations in streambed sediments increased in the downstream direction in the Neosho River and Tar Creek, indicating input and/or flushing of zinc downstream along those stream segments, and decreased in the downstream direction between the two sites on the Spring River, indicating upstream sequestration and/or flushing of zinc-rich sediments farther downstream (fig. 10). 


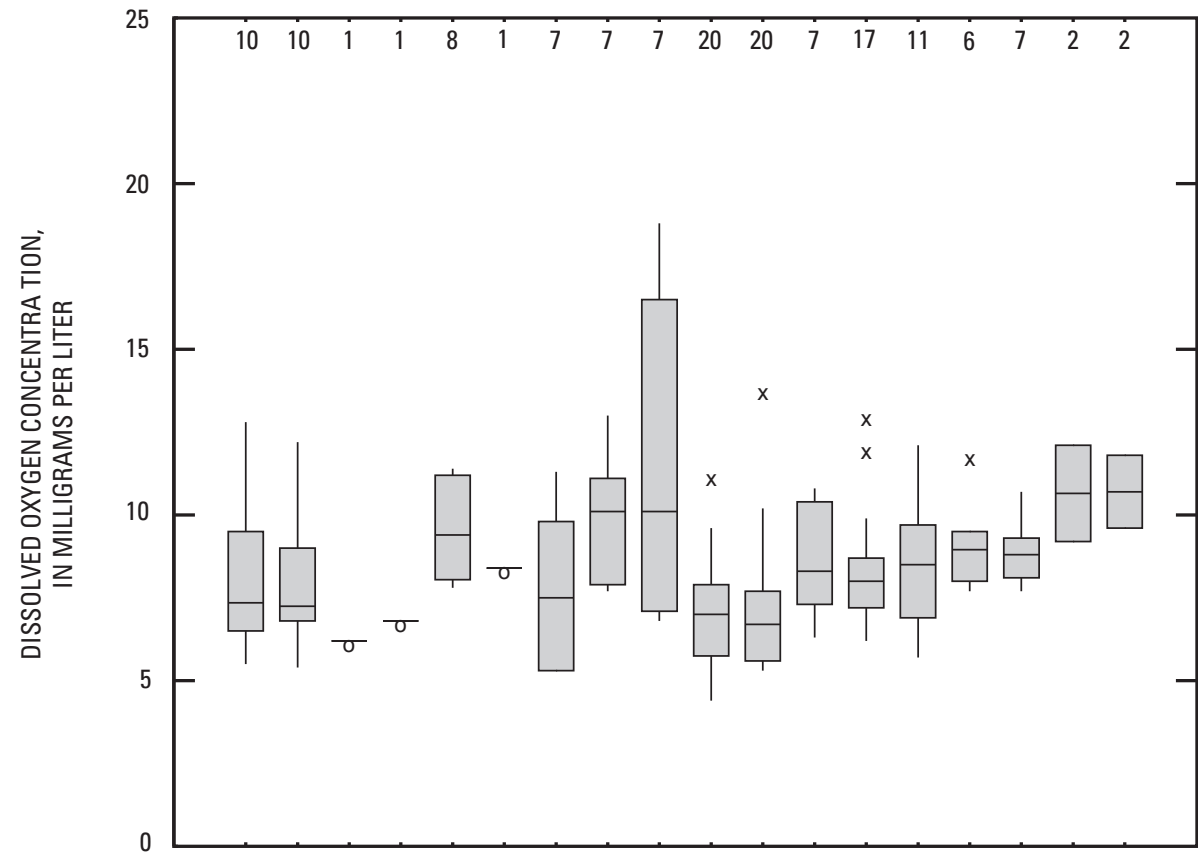

\section{EXPLANATION}

Schematic boxplot

30 Number of values

- Upper detached

x Upper outside

Upper adjacent

75 th percentile

Median

25th percentile

Lower adjacent

$x$ Lower outside

- Lower detached

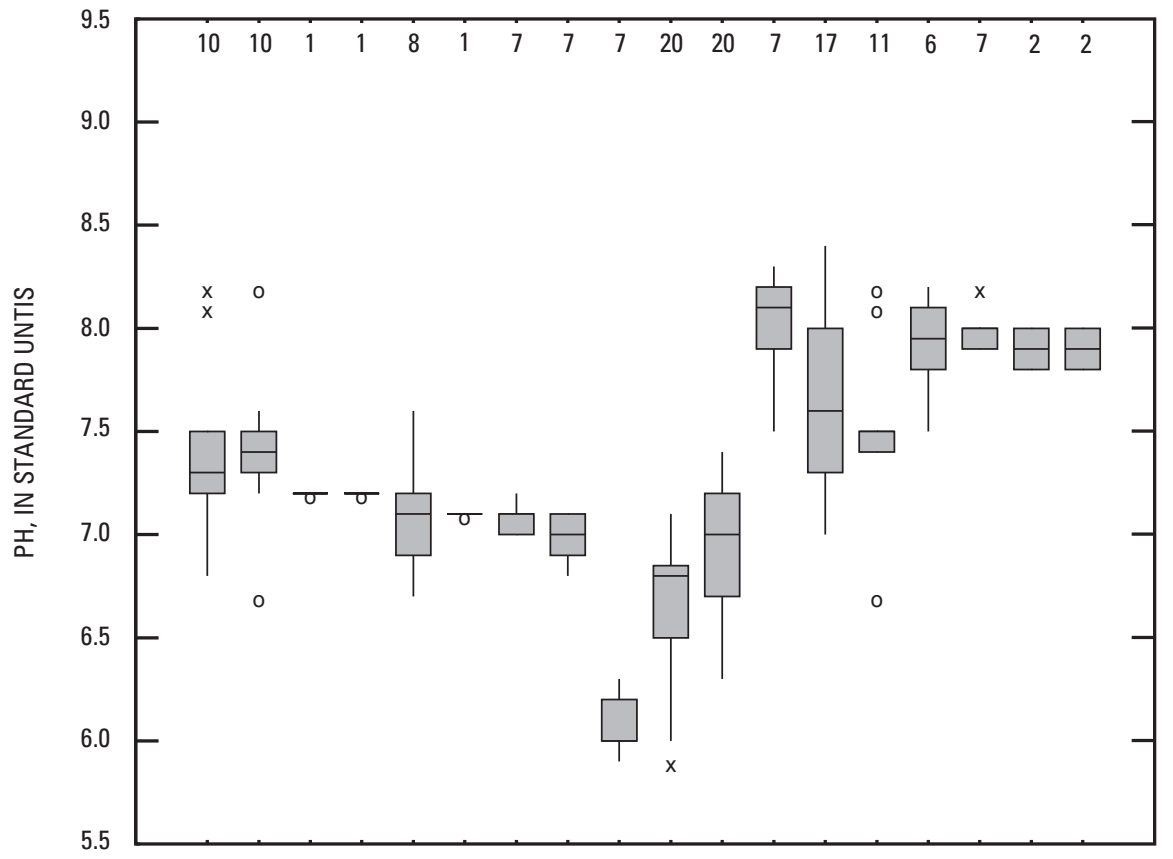

\section{EXPLANATION}

Schematic boxplot

30 Number of values

- Upper detached

x Upper outside

Upper adjacent

75th percentile

Median

25 th percentile

Lower adjacent

$x$ Lower outside

- Lower detached

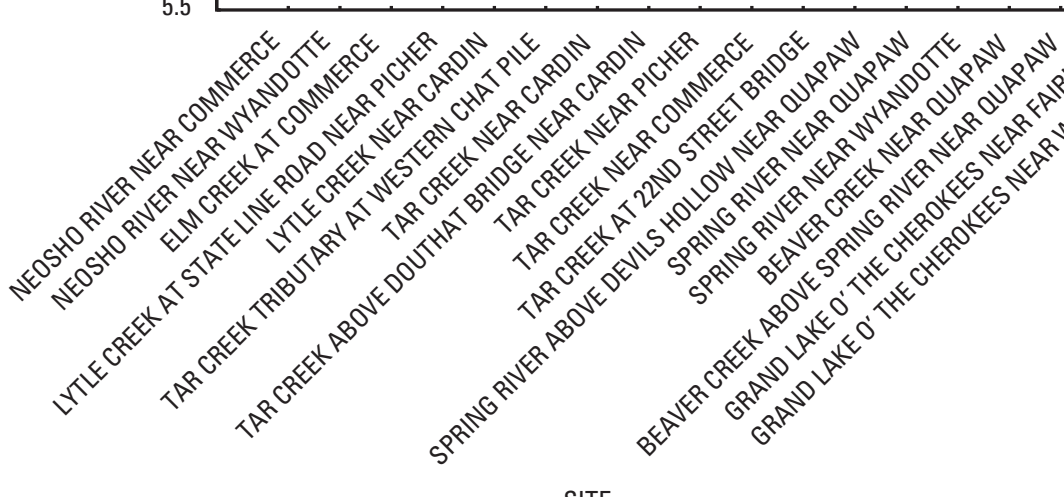

SITE

Figure 11. Ranges of concentrations of dissolved oxygen and of $\mathrm{pH}$ in water-quality samples from 18 stream sites in the $0 \mathrm{klahoma}$ part of the Tri-State mining district 2004-06. 


\section{Selected Metals in Streams}

\section{Aqueous Concentrations and Streamflow}

In the alkaline and well-oxidized conditions of local streams, many of the analyzed metals precipitate into low-solubility oxide, oxyhydroxide, and oxycarbonate minerals. Such conditions also facilitate adsorption of metals onto surfaces of abundant clay minerals, and onto complexes of iron and manganese oxyhydroxides which are abundant in local stream channels (fig. 2C and D). Because of the propensity of metals to precipitate as many different minerals or be sorbed to other minerals, total metals concentrations in these streams typically were less than metals concentrations in streambed sediments by factors ranging from hundreds to thousands

(figs. 10, 12-17).

During base flow, metals in stream water in the mining district are likely to come primarily from two sources:

(1) seepage of metals in ground water (from flooded abandoned underground mine workings and locally perched water tables) discharging to streams; and (2) leaching of metals from streambed sediments, and tailings. Runoff during wet periods may wash metals-rich sediments into local streams, increase leaching from tailings, and re-suspend metals in metalliferous streambed sediments.

\section{Aluminum}

Water samples collected from the two sites on the Neosho River (Neosho River near Commerce, Oklahoma; and Neosho River near Wyandotte, Oklahoma) had the greatest total aluminum concentrations of the sampled sites (fig. 12). Much of the Neosho River drains areas underlain by Krebs Group shales of Mississippian age (McKnight and Fischer, 1970). Similar concentrations of aluminum in water samples collected at the Neosho River near Commerce, Oklahoma, site, upstream from most of the mined areas, and at the Neosho River near Wyandotte, Oklahoma, site, downstream from most of the mined area, support the concept that little of the total aluminum in water in that river is associated with the mined area, despite the fact that tailings in the mining district contained from about 2,000 to $20,000 \mathrm{mg} / \mathrm{Kg}$ of aluminum (table 1). Total aluminum concentrations for two of the sites on the Spring River (Spring River near Quapaw, Oklahoma; and Spring River near Wyandotte, Oklahoma) were about an order of magnitude (10 times) less than in water samples collected at the two Neosho River sites (fig. 12A), possibly because a much greater proportion of the Spring River Basin is underlain by limestones of the Mississippian age Boone Formation, rather than by aluminum-rich shales (McKnight and Fischer, 1970). Water samples collected from Tar Creek generally had smaller concentrations of total aluminum than water samples collected from the Neosho and Spring Rivers (fig. 12A). Tar Creek has a much smaller drainage area than those rivers and much smaller streamflows capable of transporting clays, but a greater proportion of mined lands in the basin (table 7). If tailings were the primary source of aluminum to surface water in the mining district, then total aluminum concentrations should have been greater in Tar Creek than in the rivers. Total aluminum concentrations were similar between upstream and downstream stations on the Neosho River and Tar Creek, but increased slightly in the downstream direction on the Spring River (fig. 12A).

Total aluminum concentrations generally increased with streamflow at stations on the Neosho and Spring Rivers and on Tar Creek (figs. 12B and C). Such consistent increases in aluminum with increasing streamflow at those sites further support the concept that particulate aluminum is likely to be predominantly from runoff and/or re-suspension of clayey, aluminum-rich streambed sediments at higher flows, rather than an indicator of the effects of mining on surface-water quality.

All filtered (dissolved) water samples contained less than the minimum reporting level $300 \mu \mathrm{g} / \mathrm{L}$ for aluminum. A smaller minimum reporting level for dissolved aluminum probably would have produced fewer censored data for samples from these sites.

\section{Cadmium}

Cadmium is a trace metal substituting in the structure of the zinc sulfide mineral sphalerite (Hem, 1992), but may be more likely to remain in solution than zinc on weathering of sphalerite. Tailings in this mining district contained ratios of cadmium:lead:zinc of about 1:10:100 (table 1, Datin and Cates, 2002; Schaider and others, 2007). Cadmium, like many other metals, can be adsorbed by manganese oxides, clays, and organic matter (Hem, 1992, p. 142; Drever, 1988, p. 352-382) that may impede or facilitate transport in water, depending on the nature of the particles to which cadmium is adsorbed and local streamflow and streambed characteristics.

Cadmium in water, particularly in drinking water, poses a threat to the health of humans and a variety of other terrestrial and aquatic organisms. Excessive intake of cadmium by humans has been associated with health-degrading conditions such as lung damage, kidney disease, bone degradation, and irritation of the digestive tract (Agency for Toxic Substances and Disease Registry, 1999a). Cadmium also has been determined to be "reasonably anticipated to be carcinogenic" (Agency for Toxic Substances and Disease Registry, 1999a). Akesson and others (2005) reported that damage may be sustained by human kidneys from exposure to cadmium at concentrations previously assumed to be safe. According to World Health Organization (1996), rates of absorption and retention of cadmium are greater in children, with cadmium progressively accumulating in the kidneys with age.

Most total and dissolved cadmium concentrations were less than the DEQ laboratory minimum reporting level of $5 \mu \mathrm{g} / \mathrm{L}$ (fig. 13A). Water samples analyzed for projects completed prior to 2004 by the USGS were analyzed at the USGS 
A
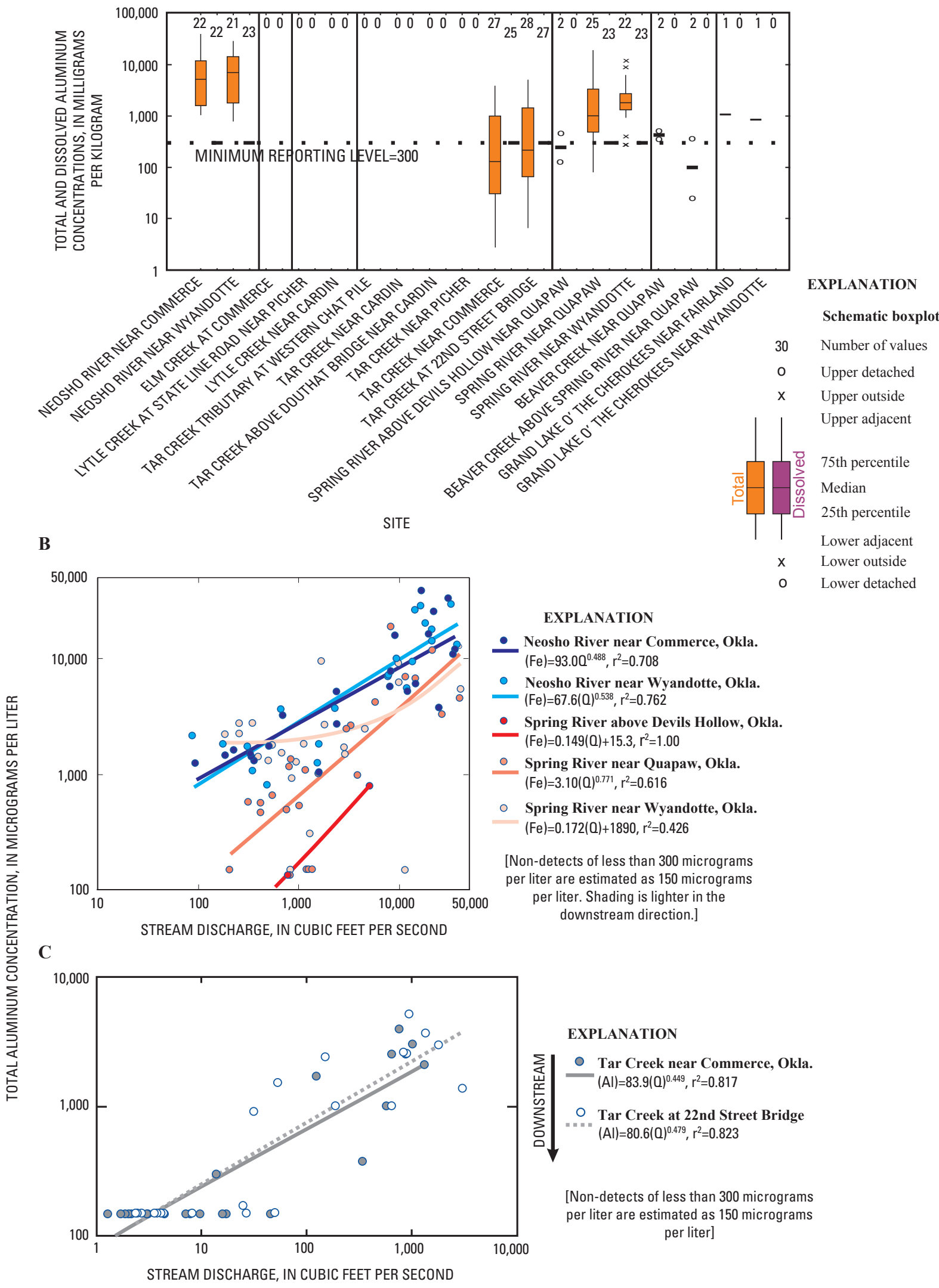

Figure 12. Ranges in concentrations of total and dissolved aluminum (A), and graphs of total concentrations of aluminum in surfacewater samples compared to discharge $(\mathrm{B}, \mathrm{C})$ for samples collected at sites in the Oklahoma part of the Tri-State mining district, 2000-06. 
$\mathbf{A}$
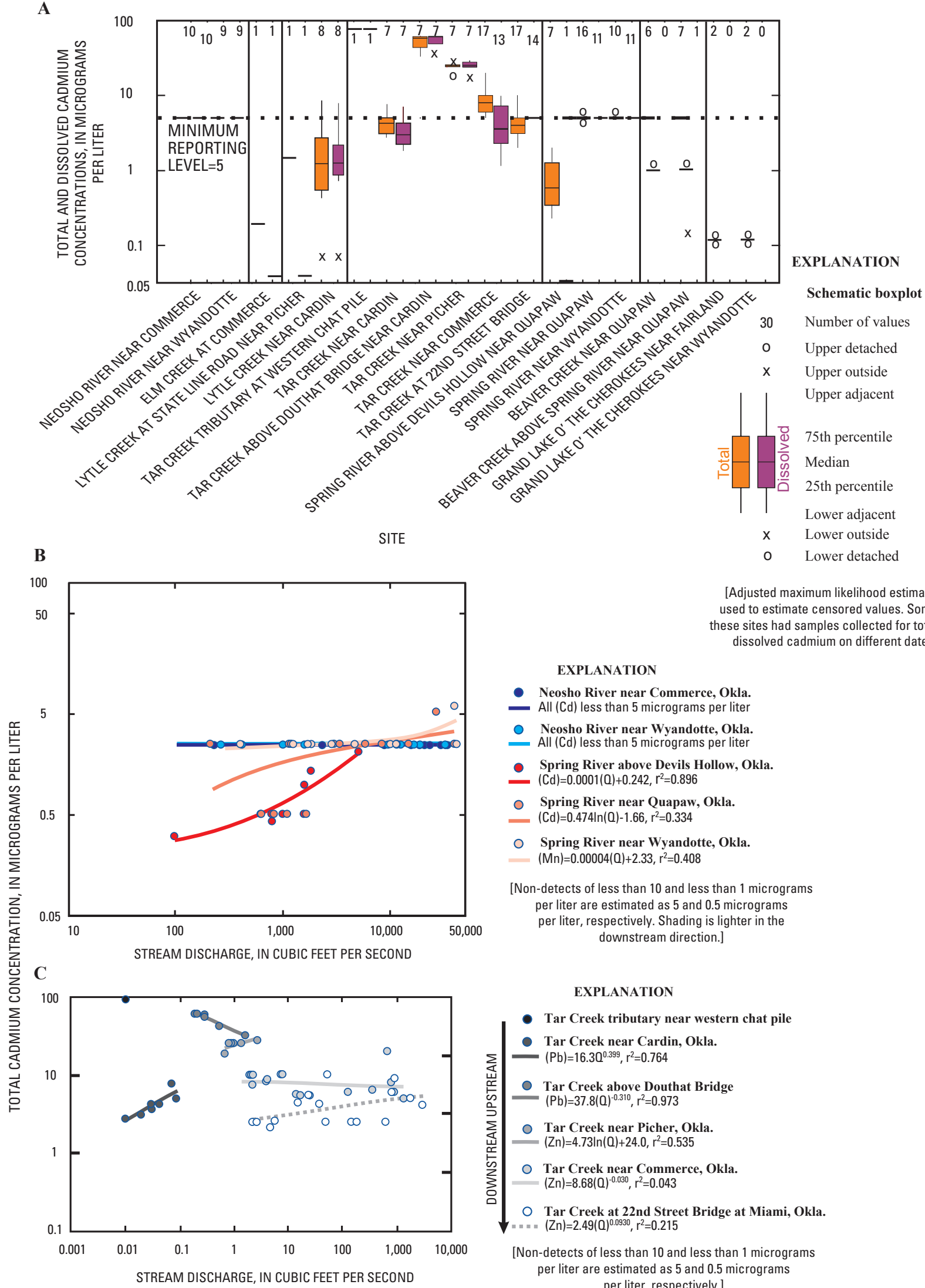

[Adjusted maximum likelihood estimation used to estimate censored values. Some of these sites had samples collected for total and dissolved cadmium on different dates]

\section{EXPLANATION}

- Neosho River near Commerce, Okla.

- All (Cd) less than 5 micrograms per liter

- Neosho River near Wyandotte, Okla.

- All (Cd) less than 5 micrograms per liter

- Spring River above Devils Hollow, Okla.

(Cd $)=0.0001(0)+0.242, r^{2}=0.896$

- Spring River near Quapaw, Okla.

- (Cd) $=0.474 \ln (0)-1.66, r^{2}=0.334$

○ Spring River near Wyandotte, Okla.

$(\mathrm{Mn})=0.00004(0)+2.33, r^{2}=0.408$

[Non-detects of less than 10 and less than 1 micrograms per liter are estimated as 5 and 0.5 micrograms per liter, respectively. Shading is lighter in the downstream direction.]

\section{EXPLANATION}

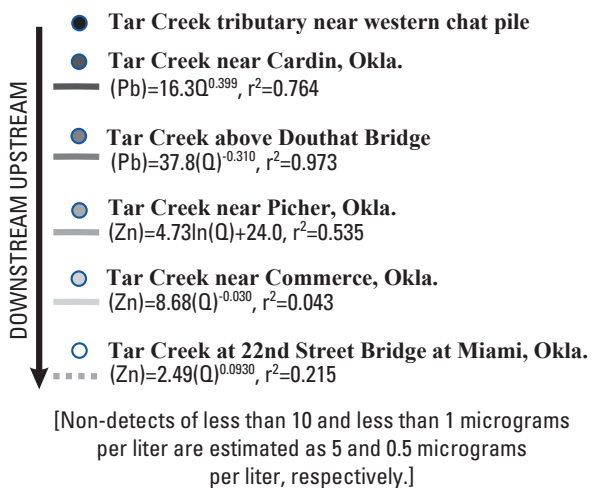

Figure 13. Ranges in concentrations of total and dissolved cadmium (A), and graphs of total concentrations of cadmium in surfacewater samples compared to discharge $(B, C)$ for samples collected at sites in the Oklahoma part of the Tri-State mining district, $2000-06$. 

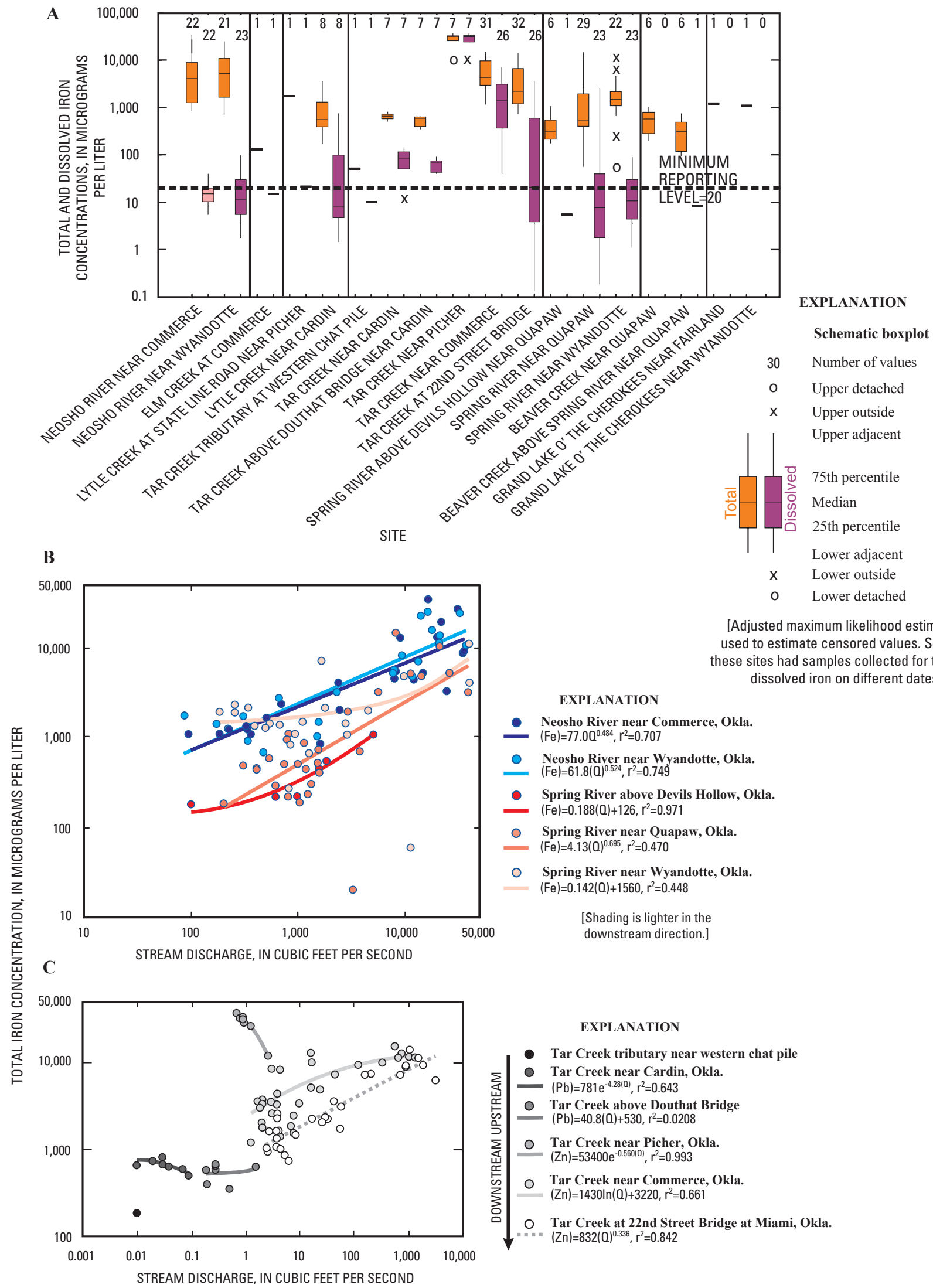

Figure 14. Ranges in concentrations of total and dissolved iron (A), and graphs of total concentrations of iron in surface-water samples compared to discharge $(B, C)$ for samples collected at sites in the Oklahoma part of the Tri-State mining district, 2000-06. 
$\mathbf{A}$
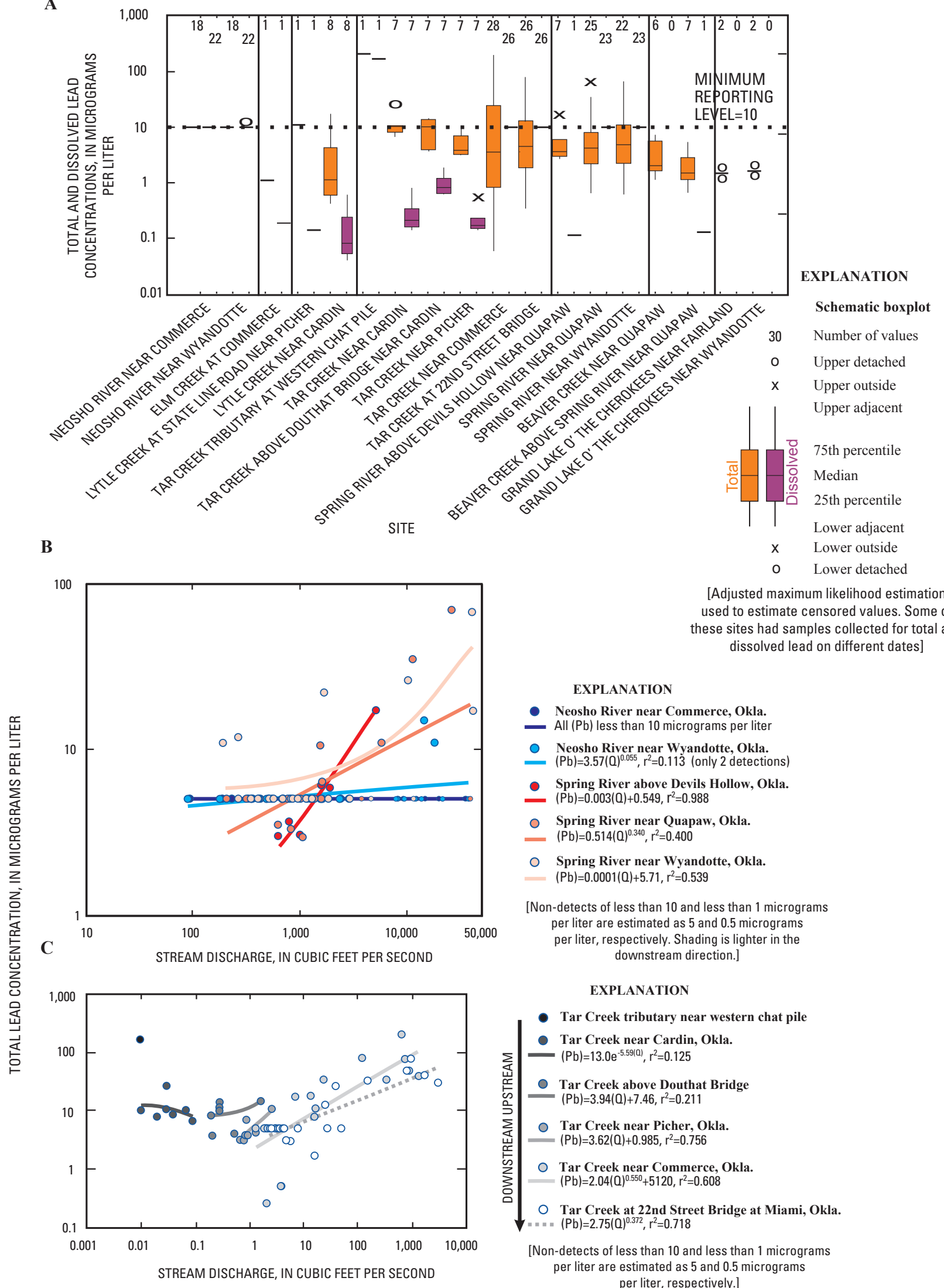

[Adjusted maximum likelihood estimation used to estimate censored values. Some of these sites had samples collected for total and dissolved lead on different dates]

\section{EXPLANATION}

- Neosho River near Commerce, Okla.

All $(\mathrm{Pb})$ less than 10 micrograms per liter

- Neosho River near Wyandotte, Okla.

- $(\mathrm{Pb})=3.57(0)^{0.055}, \mathrm{r}^{2}=0.113$ (only 2 detections)

- Spring River above Devils Hollow, Okla.

- $(\mathrm{Pb})=0.003(0)+0.549, r^{2}=0.988$

- Spring River near Quapaw, Okla.

$(\mathrm{Pb})=0.514(0)^{0.340}, r^{2}=0.400$

○ Spring River near Wyandotte, Okla.

$(\mathrm{Pb})=0.0001(\mathrm{Q})+5.71, \mathrm{r}^{2}=0.539$

[Non-detects of less than 10 and less than 1 micrograms per liter are estimated as 5 and 0.5 micrograms per liter, respectively. Shading is lighter in the downstream direction.]

\section{EXPLANATION}

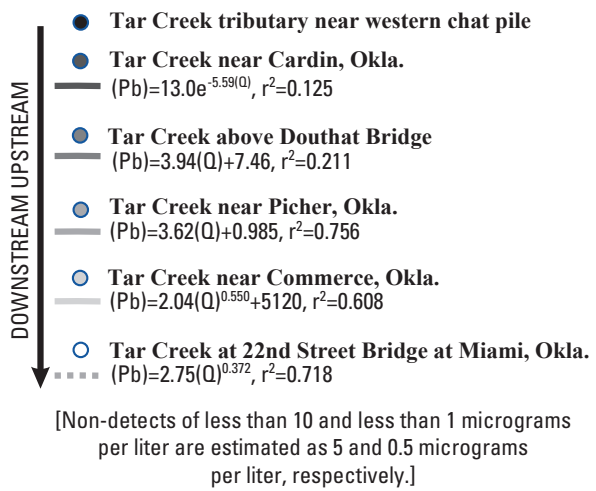

Figure 15, Ranges in concentrations of total and dissolved lead (A), and graphs of total concentrations of lead in surface-water samples compared to discharge $(B, C)$ for samples collected at sites in the Oklahoma part of the Tri-State mining district, $2000-06$. 

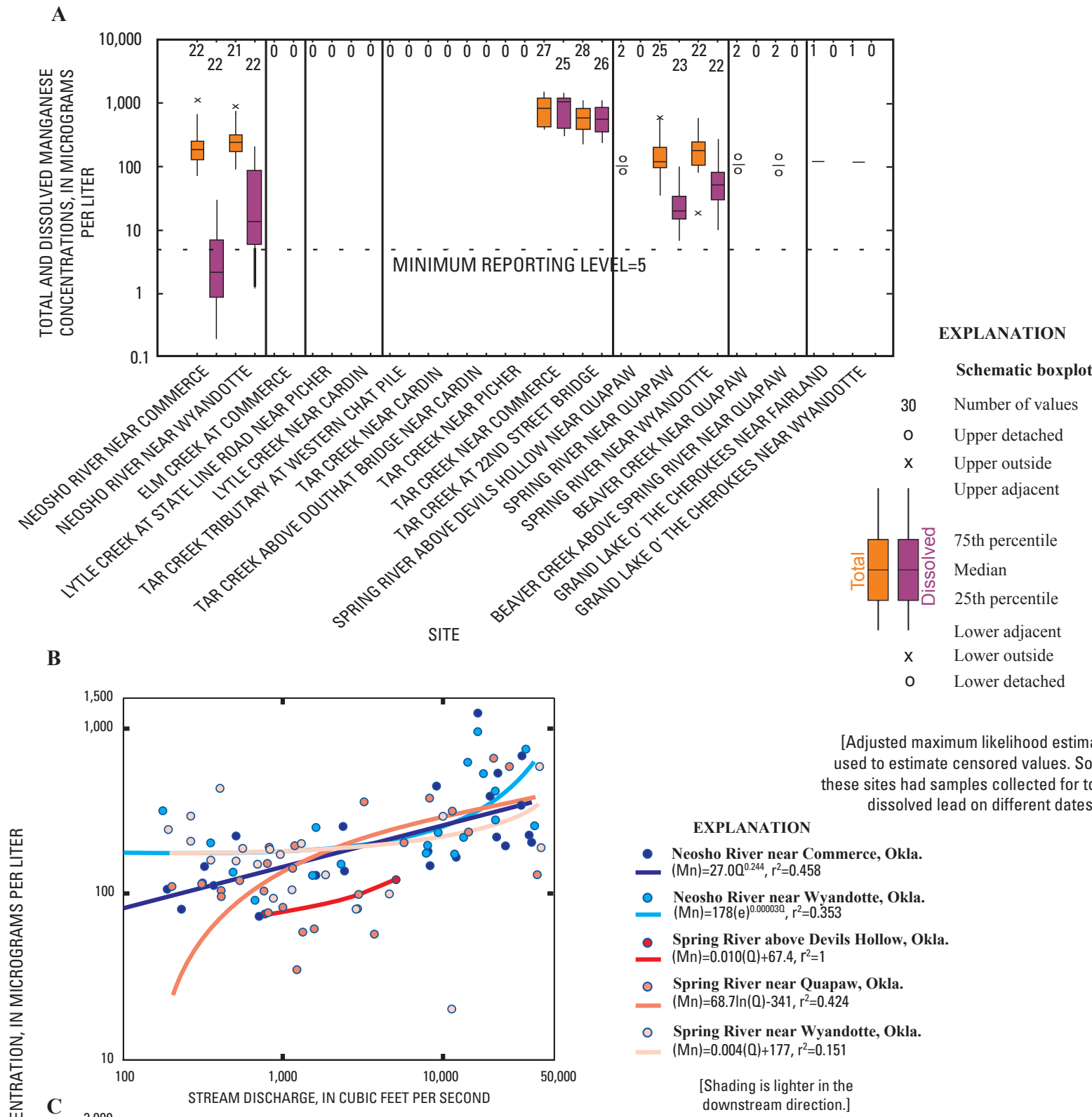

[Adjusted maximum likelihood estimation used to estimate censored values. Some of these sites had samples collected for total and dissolved lead on different dates] EXPLANATION

- Neosho River near Commerce, Okla

- $(\mathrm{Mn})=27.00^{0.244}, \mathrm{r}^{2}=0.458$

- Neosho River near Wyandotte, Okla.

- $(\mathrm{Mn})=178(\mathrm{e})^{.000030}, \mathrm{r}^{2}=0.353$

Spring River above Devils Hollow, Okla

- $(\mathrm{Mn})=0.010(0)+67.4, \mathrm{r}^{2}=1$

Spring River near Quapaw, Okla.

- $(\mathrm{Mn})=68.7 \mathrm{ln}(0)-341, \mathrm{r}^{2}=0.424$

- Spring River near Wyandotte, Okla.

- $(\mathrm{Mn})=0.004(0)+177, r^{2}=0.151$

[Shading is lighter in the

downstream direction.]

\section{EXPLANATION}
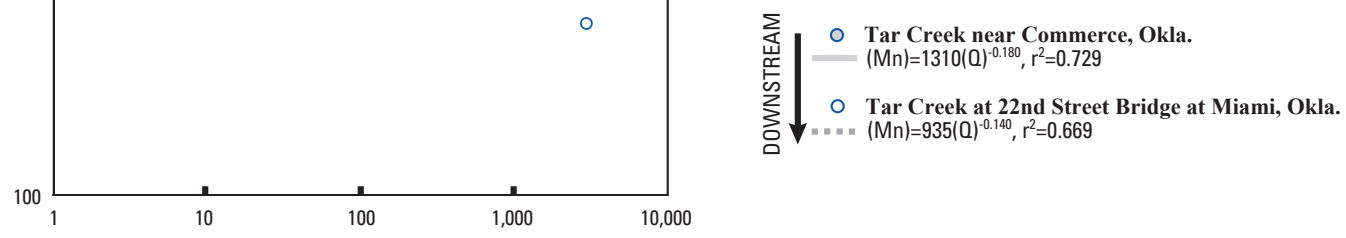

Figure 16. Ranges in concentrations of total and dissolved manganese (A), and graphs of total concentrations of manganese in surface-water samples compared to discharge $(B, C)$ for samples collected at sites in the Oklahoma part of the Tri-State mining district, 2000-06. 


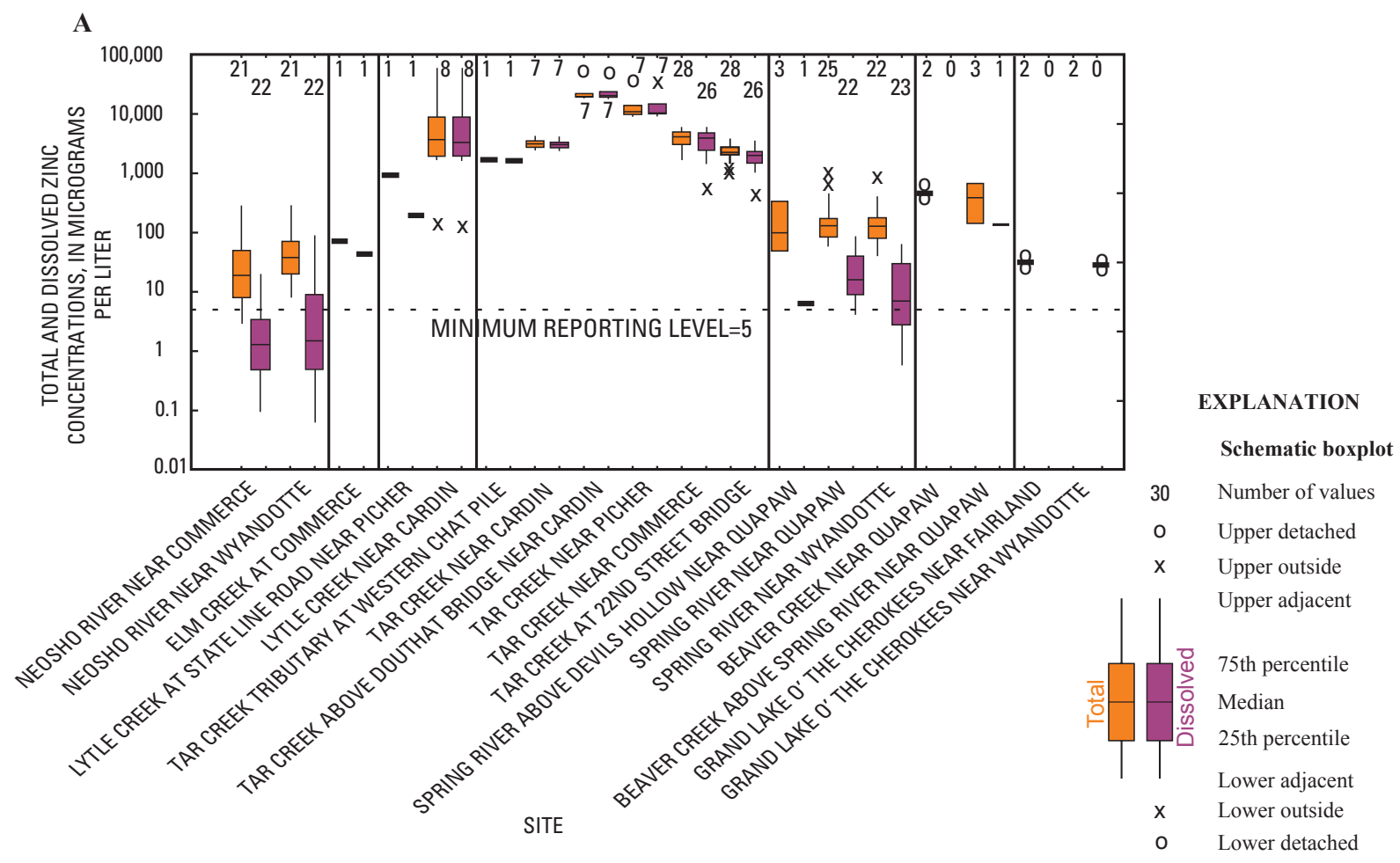

B

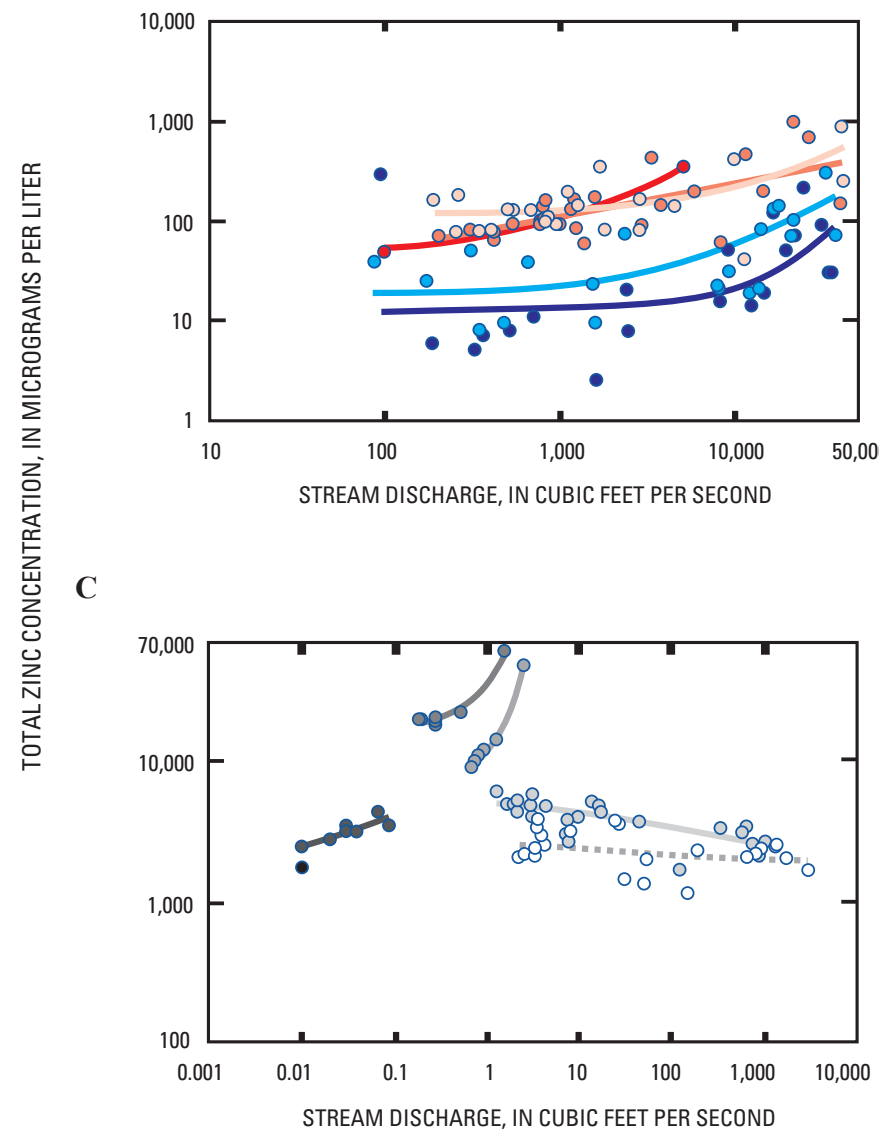

[Adjusted maximum likelihood estimation used to estimate censored values. Some of these sites had samples collected for total and dissolved lead on different dates]

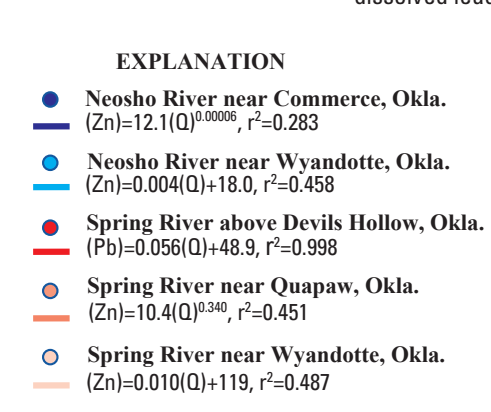

[Non-detects of less than 5 micrograms per liter are estimated as 2.5 micrograms per liter. Shading is lighter in the downstream direction.]

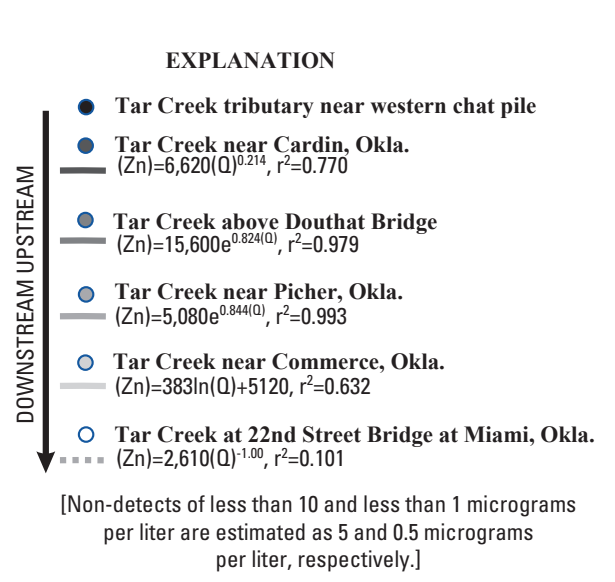

Figure 17. Ranges in concentrations of total and dissolved zinc (A), and graphs of total concentrations of zinc in surface-water samples compared to discharge $(B, C)$ for samples collected at sites in the Oklahoma part of the Tri-State mining district, $2000-06$. 
Table 7. Mined areas compared to basin areas for selected basins in the Oklahoma part of the Tri-State mining district.

[areas in square miles, mined areas estimated from Brichta, 1960]

\begin{tabular}{lccc}
\hline \multicolumn{1}{c}{ Basin } & Mined area in basin & Basin area & $\begin{array}{c}\text { Proportion of mined area } \\
\text { to basin area }\end{array}$ \\
\hline $\begin{array}{l}\text { Neosho River above Twin } \\
\text { Bridges }\end{array}$ & 20.9 & 6,130 & 0.341 \\
$\begin{array}{l}\text { Tar Creek at 22nd Street Bridge } \\
\quad \text { in Miami, Okla. }\end{array}$ & 18.0 & 44.7 & 40.2 \\
Spring River above Twin Bridges & 49.1 & 2,590 & 1.90 \\
\hline
\end{tabular}

National Water Quality Laboratory, which used methods having minimum reporting levels for cadmium as small as 0.05 $\mu \mathrm{g} / \mathrm{L}$. The largest cadmium concentrations, from 50 to 100 $\mu \mathrm{g} / \mathrm{L}$, were detected in water samples collected from upstream parts of Tar Creek (fig. 13A), where Cope and others (2008) estimated that nearly 70 percent of the cadmium in the creek was from leachate from tailings and about 25 percent was from outflow from the flooded underground mines. Similar total and dissolved concentrations of cadmium indicate that most cadmium is in the dissolved phase, or in very small suspended particles less than 0.45 microns in diameter (the typical effective pore size of field water-quality filters). Predominance of cadmium in the dissolved phase in local streams from the dissolution of sphalerite in the mining district was described previously by Carroll and others (1998) and O'Day and others (1998). All water samples from the upstream end of Tar Creek, in the center of the mining district, had cadmium concentrations greater than the 0.898 and $0.863 \mu \mathrm{g} / \mathrm{L}$ freshwater aquatic life Criteria Maximum Concentration (CMC) and Criteria Chronic Concentration (CCC) (at 300 milligrams per liter ( $\mathrm{mg} / \mathrm{L}$ ) hardness as calcium carbonate), respectively (U.S. Environmental Protection Agency, 2006), indicating potential toxic effects to aquatic life in the creek from cadmium.

Cadmium concentrations in water samples collected from the Spring River above Devils Hollow site generally increased with streamflow (fig. 13B), indicating that runoff or resuspension of streambed sediments may be the primary sources of cadmium in water at that site. Relations of cadmium concentrations to streamflow in Tar Creek were varying, decreasing with greater streamflows at the Tar Creek above Douthat Bridge site, but increasing with streamflow at the upstream site near Cardin, Oklahoma, and the downstream site near Picher, Oklahoma.

\section{Iron}

Most iron in local streams is probably initially discharged in the ferrous form $\left(\mathrm{Fe}+{ }^{2}\right)$ from anoxic waters in mine outflows containing tens of thousands of micrograms per liter of iron, as described in Cope and others (2008), DeHay (2003), and DeHay and others (2004). When those waters discharge at the land surface, bacterially mediated precipitation of iron oxides and hydroxides happens almost immediately in aerobic stream water, creating thick deposits of soft, flocculated botryoidal goethite and other iron oxide and hydroxide minerals that impair aquatic habitat and are subject to re-suspension and washing downstream during high flows (fig. 2C and 2D).

Although iron is more likely to be an indicator of runoff or seepage from the mined area than aluminum as a result of substantial amounts of pyrite, marcasite, and other iron minerals in the mines (McKnight and Fischer, 1970) and in tailings (table 1), patterns of relative ranges in iron concentrations at the sampled sites were similar to ranges of aluminum (figs. $12 \mathrm{~A}$ and 14A). Aluminum and iron concentrations in local tailings were similar (table 1), though aluminum concentrations generally have been reported to be much less in the flooded underground mine workings (DeHay, 2003; DeHay and others, 2004).

The greatest concentrations of total iron generally were measured at the Neosho River sites (fig. 14). Comparatively large concentrations of total iron in water from the Neosho River sites, which have lesser proportions of mined area than most of the other sampled sites (table 7), may be a result of natural runoff of ferruginous soils developed on shales in that basin. Dissolved iron concentrations were about equal to total iron concentrations at the Tar Creek near Picher, Oklahoma site (fig. 14A), which is downstream from several mine seeps, indicating that most of the iron in water at that site is dissolved in the reduced ferrous form, similar to ground water in the underground mine workings or perhaps seeping out of anoxic zones in iron-rich streambed sediments. Decreases in concentrations of total iron and increases in proportions of total iron to dissolved iron downstream from that site are probably a result of precipitation of iron into a variety of ferric $\left(\mathrm{Fe}^{+}{ }^{3}\right)$ iron oxide and hydroxide minerals on streambeds and banks (fig. 2). Total iron concentrations in Tar Creek in the 
mid-1980s commonly exceeded 100,000 $\mu \mathrm{g} / \mathrm{L}$ (Parkhurst, 1987); therefore, iron concentrations have decreased since that time.

Similar to aluminum, total iron concentrations increased with streamflow at sites on the Neosho and Spring Rivers (figs. 12B and $\mathrm{C}$ and 14B and C), probably a result of a combination of runoff of these metals in particles eroded from soils and tailings, and re-suspension of fine streambed particles containing these metals during high streamflows. Conversely, at several of the upstream sites on Tar Creek sampled after a storm in August 2005, decreases in total iron concentrations with increasing streamflow occurred (Cope and others, 2008), indicating the seepage of ground water from the mine workings was diluted by storm runoff and that ground-water seepage from the mines may be the predominant source of iron in upstream parts of the creek under most flow conditions (fig. 13C).

\section{Lead}

Lead has comparatively low solubility in aquatic systems because of a propensity to precipitate as oxide, carbonate, and sulfide minerals and to be adsorbed to oxides and hydroxides of iron and manganese, phosphate, clays, and organic particles (Drever, 1988, p. 342-344; Hem, 1992, p. 143; Morel and Hering, 1993, p. 521-525; Carroll and others, 1998; O'Day and others, 1998). Lead in drinking water and food poses substantial threats to the health of humans and other organisms. Lead has been known for 3,000 years to be a potent, bioaccumulative neurotoxin that can cause permanent mental, emotional, and physical impairments (North Dakota Department of Health, 2004; Karmaus and others, 2005; Lanphear and others, 2005). Consumption of lead by pregnant women has been associated with premature births, smaller birth weights, decreased mental ability in infants, and spontaneous abortion (Gray, 2004). Lead accumulates in central nervous system tissues of children at greater rates than in adults, partially because of greater uptake of many elements for growth and incomplete development of the blood-brain barrier in children (World Health Organization, 1996; New South Wales Environmental Protection Agency, 2003). Consumption of lead by children has been implicated in impaired development, lower IQs, shortened attention spans/hyperactivity, and progressive mental deterioration (loss of motor skills, severe aggressive behavior disorders, and convulsive disorder) (Gray, 2004). Effects of lead consumption on adults may include: decreased reaction time, decreased memory, weakness in fingers, wrists, and ankles; anemia, weakness, palsy, lassitude, insomnia, facial pallor, weight loss, anorexia, malnutrition, constipation, nausea, abdominal pain, vomiting, increased blood pressure in men, kidney damage, and damage to male reproductive systems (Agency for Toxic Substances and Disease Registry, 1999b; Gray, 2004). The compounds lead acetate and lead phosphate are believed to be likely carcinogens for humans (Agency for Toxic Substances and Disease Registry, 1999b).
Total lead concentrations in local tailings ranged from hundreds to thousands of milligrams per kilogram (table 1, Datin and Cates, 2002; Schaider and others, 2007), but lead concentrations have been reported to be less than $1,000 \mu \mathrm{g} / \mathrm{L}$ in ground water in the mine workings (DeHay, 2003; DeHay and others, 2004). Cope and others (2008) estimated that in the upper reaches of Tar Creek, leachate from tailings accounted for almost 70 percent of lead in water, with seepage from mines contributing almost 30 percent of the lead in the Creek.

Because most lead concentrations in the water samples were censored, greater uncertainty exists regarding relations between lead concentrations and streamflow than for most of the other metals. For the two sites on the Neosho River, no water samples had lead concentrations greater than the minimum reporting level of $10 \mu \mathrm{g} / \mathrm{L}$ at the upstream site near Commerce, Oklahoma, and only 2 of 22 samples had detectable lead concentrations (but only slightly greater than the minimum reporting level of $10 \mu \mathrm{g} / \mathrm{L})$ at the downstream site near Wyandotte, Oklahoma (fig. 15A). The greatest concentrations of lead were measured at the Tar Creek near Commerce, Oklahoma, station, but only 12 of 28 samples collected at that site contained lead at concentrations greater than the $10 \mu \mathrm{g} / \mathrm{L}$ minimum reporting level, with most total lead concentrations in water from that site being less than $100 \mu \mathrm{g} / \mathrm{L}$ (fig. 15A). Water samples collected during August 2005 to investigate the roles of storm runoff and ground-water seepage in metals transport had lead concentrations greater than the minimum reporting level for sites on the upstream part of Tar Creek, but a smaller minimum reporting level $(1 \mu \mathrm{g} / \mathrm{L})$ was associated with those samples (Cope and others, 2008). Most water samples collected from the Spring River and Beaver Creek had lead concentrations less than $10 \mu \mathrm{g} / \mathrm{L}$ (fig. 15A), consistent with the low solubility of lead in water (Hem, 1992, p. 143).

Because of the potential toxic effects of lead to aquatic biota, the EPA has established Criterion Continuous and Criterion Maximum Concentrations (CCC and CMC) for lead in freshwater aquatic systems for protection of aquatic life of 2.2 and $140 \mu \mathrm{g} / \mathrm{L}$, respectively, at a hardness of 300 milligrams per liter (mg/L) as calcium carbonate (U.S. Environmental Protection Agency, 2006). A few samples collected from sites on Tar Creek exceeded the CCC and CMC criteria. Water samples collected from the Spring River and Beaver Creek periodically exceeded the $\mathrm{CMC}$ and many of the samples exceeded the $\mathrm{CCC}$ for lead at that hardness, indicating potential threats to aquatic biota from lead in those streams. Because of concern over potential lead contamination of fish in rivers draining the mining district in Oklahoma, the DEQ sampled fish and in those streams, reporting that fillets from fish caught in ponds in the Tar Creek Superfund Site and the Neosho and Spring Rivers are safe to eat at rates as much as six 8-ounce meals per month, but that whole-uneviscerated and wholeeviscerated parts of all fish from those streams should not be consumed (Oklahoma Department of Environmental Quality, 2003). Beyer and others (2004) reported that several species of songbirds and waterfowl sampled from the mining district 
had increased lead concentrations in tissues compared to birds sampled at a reference site, and that exposure of songbirds to lead was comparable with that of birds observed at other sites severely contaminated with lead. Several birds sampled by Beyer and others (2004) had lead concentrations in tissues that have been associated with impaired biological functions and external signs of poisoning. In the late 1990s, as much as 40 percent of children in some areas of the mining district had elevated (greater than 10 milligrams per deciliter) blood-lead levels (State of Oklahoma, 2000b).

Total lead concentrations at the upstream site on the Neosho River (near Commerce, Oklahoma) were all less than the minimum reporting level, therefore no relation between streamflow and lead concentration could be determined at that site. At the downstream sampling site (Neosho River near Wyandotte, Oklahoma), the only measurable total lead concentrations were measured during high-flow periods, indicating some potential for transport of lead into the lake from the Neosho River as a result of runoff from the land surface or resuspension of lead-containing particles in streambed sediments (fig. 14B). At the upstream Tar Creek near Cardin, Oklahoma, site, a negative trend of total lead concentration with increasing streamflow may indicate that ground-water seepage is a prominent source of lead. Sites on Tar Creek downstream from the Tar Creek near Cardin, Oklahoma, site had total lead detections and concentrations generally increasing with streamflow (fig. 15C), indicating that storm runoff may be increasing lead concentrations at those sites by washing leadbearing particles from the land surface and/or re-suspending lead-bearing particles in streambed sediments.

\section{Manganese}

Manganese and iron tend to have similar chemistry, with particles of oxide and hydroxide minerals of both metals adsorbing other metals (Hem, 1992, p. 85). Manganese concentrations were about 1 percent of iron concentrations in tailings samples collected in the mining district (table 1). Dissolved manganese concentrations reported in DeHay (2003) and DeHay and others (2004) ranged from less than $1 \mu \mathrm{g} / \mathrm{L}$ to about $1,500 \mu \mathrm{g} / \mathrm{L}$, or about 1 to 10 percent of iron dissolved in ground water in the flooded underground mine workings.

Total manganese concentrations in water samples collected at the two sites on the Neosho River ranged from less than 100 to about $1,000 \mu \mathrm{g} / \mathrm{L}$; whereas, water samples from Tar Creek had total manganese concentrations ranging from about 400 to $1,500 \mu \mathrm{g} / \mathrm{L}$, and water samples from the Spring River had total manganese concentrations ranging from about 70 to $600 \mu \mathrm{g} / \mathrm{L}$ (fig. 16A).

Dissolved manganese concentrations generally were an order of magnitude less than total manganese concentrations in water samples collected at sites on the Neosho and Spring Rivers (fig. 16A), indicating the importance of transport of particulate manganese in those large streams. For the two sites on Tar Creek sampled for manganese, similar ranges in total and dissolved manganese concentrations indicated predominance of the dissolved phase of manganese under most flow conditions. Similarity of total and dissolved manganese concentrations at those sites may have been a result of the predominance of ground-water seepage as a source of that metal in that smaller stream and/or to smaller reservoirs of metal-rich sediments in the streambed. Most total manganese concentrations in Tar Creek in the mid-1980s exceeded $1,500 \mu \mathrm{g} / \mathrm{L}$ (Parkhurst, 1987), therefore, manganese concentrations have decreased slightly.

Total manganese concentration generally increased with streamflow for sites sampled on the Neosho and Spring Rivers, which indicates that storm runoff and/or resuspension of manganese-containing particles from the streambeds of those rivers were prominent sources of manganese in those streams (fig. 16B). Total manganese concentrations decreasing with increasing streamflow (fig. 16C) at the two downstream sites sampled for manganese on Tar Creek (near Commerce, Oklahoma, and at 22nd Street Bridge at Miami, Oklahoma) and similarities of total and dissolved manganese concentrations in stream water at those sites compared to manganese concentrations in the mine workings (DeHay, 2003; DeHay and others, 2004) indicated that ground-water seepage was the predominant source of manganese at those sites.

\section{Zinc}

Zinc was the primary metal mined from the mining district and remains in concentrations of tens of thousands of milligrams per kilogram in fine millpond-tailing particles (table 1, Datin and Cates, 2002; Schaider and others, 2007) and in thousands to tens of thousands of micrograms per liter in ground water in the underground mine workings (DeHay, 2003; DeHay and others, 2004). After the mineral sphalerite dissolves and seeps out of the mine workings, zinc ions tend to oxidize, forming comparatively insoluble zinc oxides (such as zincite, $\mathrm{ZnO}$ ), hydroxides (such as $\mathrm{Zn}(\mathrm{OH})_{2}$ ), zinc hydroxycarbonate minerals (such as hydrozincite, $\mathrm{Zn}(\mathrm{OH})_{6}\left(\mathrm{CO}_{3}\right)_{2}$ ), and complexes with iron hydroxide minerals, particularly in wellbuffered carbonate systems common in this and other Mississippi Valley-type deposits (Hem, 1992, p. 142; Morel and Hering, 1993, p. 553-556; American Water Works Association Research Foundation, 1996; Carroll and others, 1998; O'Day and others, 1998; Paradis and others, 2006; and oral commun., Dr. Paul L. Younger, Newcastle University (U.K.), oral commun., 2006).

Although zinc is not perceived to have the same potential as cadmium and lead to impair the health of humans or wildlife, short-term (acute) consumption of excessive quantities of zinc by humans has been associated with nausea, vomiting, diarrhea, fever, and lethargy (World Health Organization, 1996; Agency for Toxic Substances and Disease Registry, 2003). Longer-term exposure to elevated zinc concentrations interferes with copper absorption, can cause anemia, alters serum lipid (blood cholesterol) ratios, and alters some types of immune response in humans (World Health Organization, 1996; Agency for Toxic Substances and Disease Registry, 
2003). Beyer and others (2004) reported that waterfowl sampled from the mining district showed signs of pancreatitis associated with zinc poisoning. Carpenter and others (2004) reported the death of a Free-flying Trumpeter Swan recovered near Picher, Oklahoma, the post-mortem analyses indicated elevated zinc concentrations in the pancreas, liver, and kidneys and resultant damages to pancreatic and renal tissues.

Total zinc was measured at concentrations ranging from about 5 to $300 \mu \mathrm{g} / \mathrm{L}$ in water samples collected at the two sites on the Neosho River (fig. 17A). The greatest total and dissolved zinc concentrations were generally detected in small streams draining the mining district (Lytle and Tar Creeks). Total zinc concentrations in those streams generally ranged from 2,000 to $20,000 \mu \mathrm{g} / \mathrm{L}$ (fig. 17A) that substantially exceeded the 423 and $426 \mu \mathrm{g} / \mathrm{L} \mathrm{CCC}$ and CMC water-quality criteria (at a hardness of $300 \mathrm{mg} / \mathrm{L}$ as calcium carbonate) for zinc set by the EPA for protection of aquatic biota in freshwater systems (U.S. Environmental Protection Agency, 2006). Total zinc concentrations for three sites sampled on the Spring River ranged from about 50 to $500 \mu \mathrm{g} / \mathrm{L}$ (fig. 17A).

Most dissolved zinc concentrations at the two sampled sites on the Neosho River were less than the minimum reporting level of $5 \mu \mathrm{g} / \mathrm{L}$ and were about an order of magnitude less than total zinc concentrations at those sites (fig. 17A). As with manganese, ranges of total and dissolved zinc concentrations at sites sampled on Lytle and Tar Creeks were similar, indicating predominance of dissolved zinc in those small streams, perhaps from ground-water seepage or leaching from metalliferous streambed sediments and tailings, as described in Cope and others (2008). Similar to the Neosho River, dissolved zinc concentrations were about an order of magnitude less than total zinc concentrations at the sites sampled on the Spring River, indicating predominance of particulate zinc in those rivers. Larger zinc concentrations in the Spring River relative to the Neosho River may be a result of a larger proportion of the drainage basin of the Spring River being mined (figs. 1 and 3, table 7). In the mid-1980s, zinc concentrations at sites on the downstream reach of Tar Creek exceeded 20,000 $\mu \mathrm{g} / \mathrm{L}$ and in the upstream reach exceeded 100,000 $\mu \mathrm{g} / \mathrm{L}$ (Parkhurst, 1987), indicating notable decreases of zinc concentrations with time in Tar Creek.

Similar to lead, total zinc concentrations at upstream sites on Tar Creek, in the center of the mining district, increased with streamflow (figs. 15C and 17C), indicating that runoff tended to wash zinc-rich particles from the land surface and/or resuspend zinc-rich particles in streambed sediments. Total zinc concentrations generally decreased with streamflow at the two Tar Creek sites downstream from the mined areas (fig. 17C) indicating that runoff, perhaps from areas downstream from the mined areas, may have diluted zinc concentrations and that ground-water seepage may have been the primary source of zinc in water at those sites. Total zinc concentrations at sites on the Neosho and Spring Rivers increased with streamflow, indicating that runoff from the land surface or resuspension of zinc-containing streambed sediments were influential factors controlling zinc concentrations in Neosho and Spring Rivers.

\section{Total Metal Loads}

Total loads indicate the flux or mass per unit of time for a substance flowing past a given point in a stream channel, including suspended and dissolved substances (total). Total metal loads can be related to geologic settings and disruptions to those settings caused by activities such as mining. The total load of a particular substance increasing in the downstream direction indicates incremental inputs of a substance along the course of a stream. Consistent total loads of a substance at the beginning and end of a stream segment indicate lack of contribution or balance between runoff/seepage and sedimentation of a substance in a particular stream reach. Total loads estimated in this section at base flows are similar in range to total load estimates described for streams at base flow in the mining district by Oklahoma Department of Environmental Quality (2008).

\section{Aluminum}

The Neosho River flows through areas underlain by shales that may contribute large amounts of aluminum in the form of clay minerals to that river. The comparatively large concentrations and streamflow of the Neosho River combined to produce the largest loads of total aluminum of the stream sites sampled near the mining district (fig. 18), with median loads of about 100,000 kilograms (100 tonnes) of aluminum per day. Similar ranges in total aluminum loads at the Neosho River station upstream from most historic mining locations (near Commerce, Oklahoma) and the Neosho River station downstream from most of the historic mining activity (near Wyandotte, Oklahoma, fig. 18) indicate that tailings and seepage from the mine workings probably contribute little aluminum to the Neosho River, as described for total aluminum concentrations in water. Only two sites on Tar Creek were sampled for total aluminum and the large minimum reporting level $(300 \mu \mathrm{g} / \mathrm{L})$ caused most of the data from those sites (18 of 25 samples for near Commerce, Oklahoma, and 16 of 28 samples for 22nd Street Bridge in Miami, Oklahoma) to be censored (non-detects). Much of the area draining to Tar Creek is underlain by Krebs Group shales (McKnight and Fischer, 1970), but about one-third of that basin is covered with tailings piles, which are dominated by crushed particles of limestones, dolomites, and cherts from the underlying Boone Formation. Aluminum loads at these Spring River sites were generally one to two orders of magnitude (10 to 100 times) less than aluminum loads from the Neosho River sites, perhaps a result of a smaller proportion of the Spring River Basin being underlain by shales containing aluminum-rich clay minerals. 


\section{Cadmium}

Estimated total cadmium loads are less certain than loads estimated for other metals in this report because most of the cadmium concentrations in water samples were censored (figs. 13 and 18). Increases in estimated cadmium loads from upstream reaches of Tar Creek (near Cardin, Oklahoma) to the downstream reach (at the 22nd Street Bridge in Miami, Oklahoma) indicated contributions of cadmium in the downstream direction, probably from a combination of mine seepage, runoff of tailings, and re-suspension of cadmium-bearing sediments during high flows.

\section{Iron}

Total iron loads, which can come from erosion and seepage from erosion of shales, local soils, tailings, and mine workings, were similar to total aluminum loads at the sampled sites (fig. 18). Additional sites, however, were sampled for iron. Total iron loads in Tar Creek increased by several orders of magnitude in the downstream direction, indicating contributions from mine seeps, runoff, dissolution of streambed sediments, and/or resuspension of abundant ferruginous sediments in the downstream direction. Iron loads at sites sampled in Lytle and Beaver Creeks, which also drain parts of mined areas, were similar to the iron loads in the upstream reaches of Tar Creek (fig. 18).

\section{Lead}

All concentrations, and thus loads, of total lead were less than the minimum reporting level at the two sites on the Neosho River, indicating that small quantities of lead were transported by that River, despite comparatively large streamflows at those sites. A smaller minimum reporting level of $1 \mu \mathrm{g} / \mathrm{L}$ for samples collected at upstream sites on Tar Creek in August 2005, rather than the $10 \mu \mathrm{g} / \mathrm{L}$ level that applied to other samples, caused there to be no censored lead data for those sites. Much greater proportions of censored data for the downstream sites (16 of 26 samples from near Commerce, Oklahoma, and 16 of 25 samples for 22nd Street Bridge in Miami, Oklahoma) contributed to less certainty about total lead loads at the downstream sites. Despite those differences in censoring of data, total lead loads increased in the downstream direction, indicating contributions from ground-water seepage, runoff, and/or dissolution and resuspension of streambed sediments along the course of Tar Creek. As with Tar Creek, a smaller minimum reporting level of $1 \mu \mathrm{g} / \mathrm{L}$ applied to samples collected at Spring River above Devils Hollow near Quapaw, Oklahoma, site, provides more reliable estimates of total lead loads. Apparent lesser total lead loads at the downstream sites near Quapaw, Oklahoma, and near Wyandotte, Oklahoma, may be a result of greater proportions of censored total lead data (17 of 24 and 16 of 21 samples, respectively) at those two sites on the Spring River (fig. 18).

\section{Manganese}

Unlike lead, total manganese had no censored data, but fewer sites were sampled for manganese. Manganese is commonly associated with iron, and has similar chemical behavior, but generally is found in smaller concentrations than iron. Although the manganese sulfide mineral alabandite $(\mathrm{MnS})$ was not reported in the mining district (McKnight and Fischer, 1970), that or other manganese minerals may be present in trace amounts with abundant iron minerals in the mines and manganese commonly is associated with iron in soils in the forms of oxide and hydroxide minerals (Hem, 1992, p. 86). As with total iron, the ranges of total manganese loads were similar in the Neosho River at the upstream (near Commerce, Oklahoma) and downstream (near Wyandotte, Oklahoma) reaches, indicating little effect of the mined area on total manganese loads (fig. 18). Ranges of total manganese loads at the Tar Creek near Commerce, Oklahoma, and at 22nd Street Bridge in Miami, Oklahoma, were similar (fig. 18), as was the case with iron loads. Ranges of total manganese loads at the Spring River near Quapaw, Oklahoma, and near Wyandotte, Oklahoma, sites were intermediate between those in the Neosho River and Tar Creek (fig. 18), also similar to total iron. Those intermediate total manganese loads may be a result of a greater proportion of the Spring River Basin having been mined than the Neosho River Basin, but a smaller proportion of the Spring River Basin being affected by mining than the Tar Creek Basin (table 7).

\section{Zinc}

Total zinc concentrations were substantially less in water samples collected at the sites on the Neosho and Spring Rivers than at the sites sampled on Lytle and Tar Creeks (fig. 17). However, streamflows of the Neosho and Spring Rivers commonly are in the tens of thousands of cubic feet per second, contributing to the comparatively large total zinc loads ranging from tens to several thousand kilograms per day. A slight increase in total zinc loads at the Neosho River near Wyandotte, Oklahoma, site compared to the upstream site near Commerce, Oklahoma, (fig. 18) may have been caused by inputs of zinc from tributary streams flowing through the mined area, particularly Tar Creek. Total zinc and total lead loads increased in the downstream direction along Tar Creek (fig. 18), indicating inputs of zinc from ground-water seepage, runoff, and/or dissolution and re-suspension of zinc- and leadcontaining streambed sediments.

\section{Summary}

The Oklahoma part of the Tri-State mining district, also known as the Picher mining district, is an abandoned lead and zinc mining district in Ottawa County, northeastern Oklahoma. During the first half of the 20th century, the district was a 


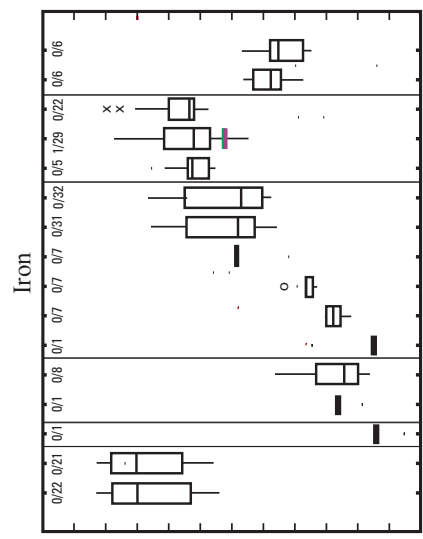

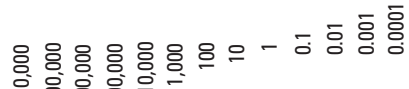

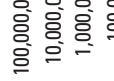

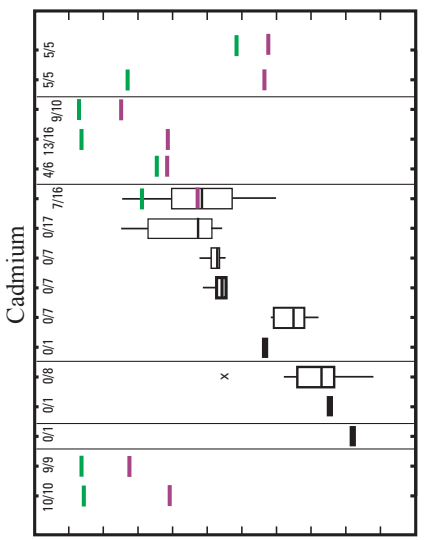

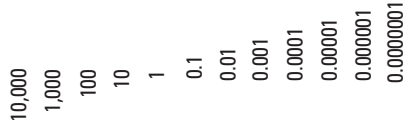
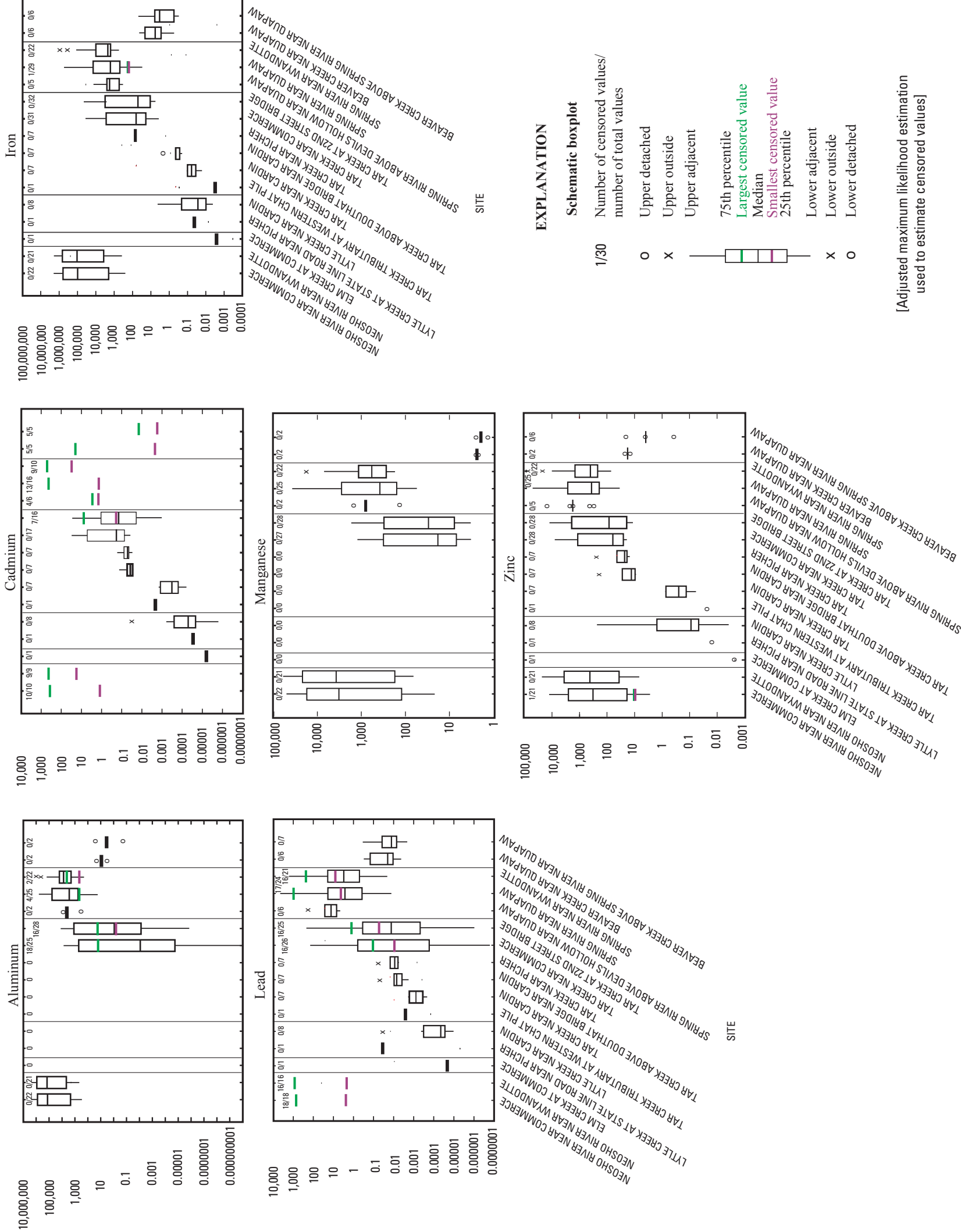

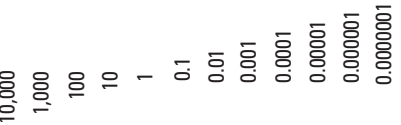

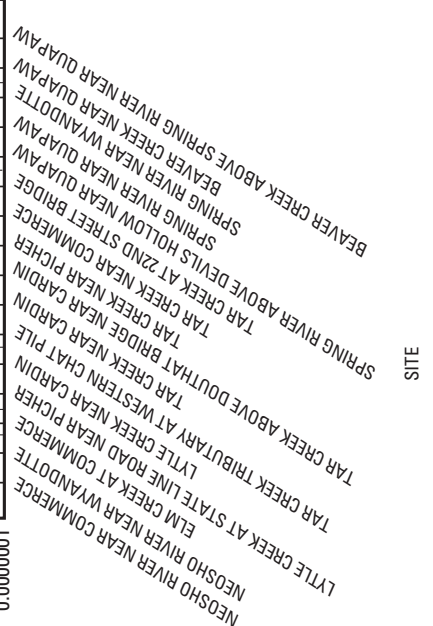


primary producer of lead and zinc in the United States. Those two metals are common in sulfide minerals of the Mississippian-age Boone Formation, which is composed primarily of limestones and dolomitic limestones. Ore production in the district was active from the late 1800s until the mid-1970s. Production reached a peak by 1925 with 387,000 tons of recoverable zinc and 101,000 tons of recoverable lead being produced. The mines maintained moderate production levels until the 1950s when yields began to decline.

Sulfide minerals of iron, lead, and zinc can gradually oxidize and dissolve in underground mine workings, and in tailings on the land surface in the mining district. A variety of low-solubility oxide, hydroxide, and hydroxycarbonate metallic minerals form as dissolved metals seeping from the mine workings and tailings oxidize further and combine with abundant dissolving carbonate minerals.

Tens of millions of tons of gravel- to sand-sized mine tailings known as "chat" remain in the mining district. Ponds of silt- and clay-sized by-products of the gravity separation process, referred to as millpond tailings, commonly lie adjacent to chat piles. Fine particles ( $<2$ millimeters in diameter) in millpond tailings in the district contain tens to hundreds of thousands of milligrams per kilogram of aluminum, iron, and zinc, with concentrations of other trace metals such as lead and cadmium ranging from tens to hundreds of milligrams per kilogram. Seepage from tailings and from flooded underground mine workings supply both water and metals to base flow of local streams.

Lakebed, streambed, and floodplain sediments and/or stream water were sampled at a total of 30 sites by the U.S. Geological Survey and the Oklahoma Department of Environmental Quality from 2000 to 2006 in cooperation with the U.S. Environmental Protection Agency, and the Quapaw and Seneca-Cayuga Tribes of Oklahoma. Aluminum and iron were measured in concentrations of several thousand milligrams per kilogram in sediments in the upstream end of Grand Lake $\mathrm{O}$ ' the Cherokees, with manganese and zinc concentrations being several hundred milligrams per kilogram. Concentrations of lead were about 10 percent of zinc concentrations and with cadmium concentrations were about 0.1 percent of zinc concentrations. A transect of sediment cores collected across the floodplain of Tar Creek near Miami, Oklahoma, in 2004 were similar to or greater than concentrations of those metals in the upstream end of Grand Lake O' the Cherokees, with the greatest concentrations of cadmium, iron, lead, and zinc being found beneath a tributary draining abandoned mined areas near Commerce, Oklahoma.

Concentrations of aluminum and iron were greatest in the Neosho River in surface-water samples collected in the Oklahoma part of the Tri-State mining district from 2000 to 2006, perhaps a result of runoff from areas overlain by shales. The greatest concentrations of cadmium, lead, manganese, and zinc were measured in Tar Creek. The Spring River had greater concentrations of zinc than the Neosho River, perhaps a result of a greater proportion of mined area in the Spring River Basin. Dissolved metals concentrations were generally much less than total metals concentrations, except for manganese and zinc at sites on Tar Creek, where ground-water seepage or seepage from metalliferous streambed sediments may be the primary sources of those metals. Concentrations of total aluminum generally increased with streamflows at all sites, probably caused by runoff and re-suspension of aluminum-rich clay particles during high flows. Total cadmium concentrations increased with streamflow at the Spring River sites and at Tar Creek near Cardin, Oklahoma, and near Picher, Oklahoma, sites, but decreased with streamflow at other sites on Tar Creek, indicating predominance of base flow (ground-water seepage) as a cadmium source at some sites, and runoff and/or re-suspension of cadmium being prominent sources of cadmium in water at other sites on Tar Creek. Total iron concentrations generally increased with greater streamflows for sites on the Neosho and Spring Rivers, but not for upstream sites on Tar Creek, where seepage of metals from ground-water or streambed sediments may be the predominant sources of iron at most flow conditions. With the majority of lead concentrations at most sites being censored, there is greater uncertainty regarding relations between lead concentrations and streamflow. Total manganese concentrations generally increased with streamflow in the Neosho and Spring Rivers, indicating possible enrichment by runoff and/ or re-suspension of metalliferous streambed sediments during higher streamflows. Decreases in manganese concentrations with increasing streamflow at the downstream sites on Tar Creek indicate dilution of manganese seeping from groundwater during higher streamflows. General increases in total zinc concentrations with higher streamflows in the Neosho and Spring Rivers and in upstream parts of Tar Creek indicate that the primary sources of total zinc concentrations at those sites were likely to be runoff and/or re-suspension of metalliferous streambed sediments. Decrease in total zinc concentrations with increasing streamflow at downstream sites on Tar Creek may indicate predominance of ground-water seepage as a source of zinc at those sites, with higher streamflows diluting zinc concentrations.

Loads (masses flowing past a given point on a stream per unit of time) of total aluminum, iron, manganese, and zinc generally were greatest at the sampled sites on the Neosho and Spring Rivers, in part a result of streamflows that regularly exceeded 10,000 cubic feet per second at those sites. Slight increases in loads in the downstream directions on those rivers indicated contributions of metals from inflows of small tributaries like Tar Creek and from runoff. Increasing loads of cadmium, lead and zinc in the downstream direction in Tar Creek indicated gains in metal flows in the downstream direction, possibly caused by combinations of ground-water seepage, seepage from streambed sediments, and runoff and resuspension of metalliferous streambed sediments at higher flows. 


\section{References Cited}

Agency for Toxic Substances and Disease Registry, 1999a, ToxFAQs for cadmium: Agency for Toxic Substances and Disease Registry, available online at URL: http://www.atsdr. cdc.gov/tfacts5.html. (Accessed Sept. 11, 2004.)

Agency for Toxic Substances and Disease Registry, 1999b, ToxFAQs for lead: Agency for Toxic Substances and Disease Registry, available online at URL: http://www.atsdr. cdc.gov/tfacts13.html. (Accessed Sept. 11, 2004.)

Agency for Toxic Substances and Disease Registry, 2003, ToxFAQs for zinc: Agency for Toxic Substances and Disease Registry, available online at URL: http://www.atsdr.cdc.gov/ tfacts60.html. (Accessed Sept. 11, 2004.)

Akesson, Agneta, Lundh, Thomas, Vahter, Marie, Bjellerup, Per, Lidfeldt, Jonas, Nerbrand, Christina, Samsioe, Goran, Stromberg, Ulf, and Skerfving, Staffan, 2005, Tubular and glomerular kidney effects in Swedish women with low environmental cadmium exposure: Environmental Health Perspectives, v. 113 , no. 11 , p. 1627-1631.

American Water Works Association Research Foundation, 1996, Internal corrosion of water distribution systems: American Water Works Association Research Foundation, $586 \mathrm{p}$.

Beyer, W.N., Dalgarn, J., Dudding, S., French, J.B., Mateo, R., Miesner, J., Sileo, L., and Spann, J., 2004, Zinc and lead poisoning in wild birds in the Tri-State mining district (Oklahoma, Kansas, and Missouri): Environmental Contamination and Toxicology, v. 48, no. 1, p. 108-117.

Brichta, L. C., 1960, Catalog of recorded exploration drilling and mine workings, Tri-State zinc-lead district, Missouri, Kansas, and Oklahoma: U. S. Bureau of Mines Information Circular IC7993, 13 p.

Carpenter, J.W., Andrews, G.A., and Beyer, W.N., 2004, Zinc toxicosis in a Free-flying Trumpeter Swan (Cygnus buccinator): Journal of Wildlife Diseases, v. 40, no. 4, p. 769-774.

Carroll, S.A., O’Day, P.A., and Piechowski, M., 1998, Rockwater interactions controlling zinc, cadmium, and lead concentrations in surface waters and sediments, U.S. Tri-State mining district. 2. geochemical interpretation: Environmental Science and Technology, v. 32, no. 7, p. 956-965.

Cohen, A.C., 1959, Simplified estimators for the normal distribution when samples are singly censored or truncated: Technometrics, v. 1, p. 207-213.
Cope, C.C., Becker, M.F., Andrews, W.J., and DeHay, Kelli, 2008, Streamflow, water quality, and metal loads from chat leachate and mine outflow into Tar Creek, Ottawa County, Oklahoma, 2005: U.S. Geological Survey Scientific Investigations Report 2007-5115, 24 p.

Datin, D.L., and Cates, D.A., 2002, Sampling and metal analysis of chat piles in the Tar Creek Superfund Site: Oklahoma Department of Environmental Quality, 69 p.

DeHay, K.L., 2003, Assessment and comparison of 1976-77 and 2002 water quality in mineshafts in the Picher mining district, northeastern Oklahoma and southeastern Kansas: U.S. Geological Survey Water-Resources Investigations Report 03-4248, $64 \mathrm{p}$.

DeHay, K.L., Andrews, W.J., and Sughru, M.P., 2004, Hydrology and ground-water quality in the mine workings within the Picher mining district, northeastern Oklahoma, 2002-03: U.S. Geological Survey Scientific Investigations Report 2004-5043, 62 p.

Drever, J.I., 1988, The geochemistry of natural waters (2nd ed.): Englewood Cliffs, N.J., Prentice Hall, 480 p.

Elder, J.F., 1988, Metal biogeochemistry in surface-water systems; A review of principles and concepts: U.S. Geological Circular 1013, 43 p.

Faires, L.M., 1993, Methods of analysis by the U.S. Geological Survey National Water Quality Laboratory-Determination of metals in water by inductively coupled plasma-mass spectrometry: U.S. Geological Survey Open-File Report 92-634, 28 p.

Ferderer, D.A., 1996, National overview of abandoned mine land sites utilizing the Minerals Availability System (MAS) and geographic information system (GIS) technology: U.S. Geological Survey Open-File Report 96-549, 42 p.

Garbarino, J.R., and Struzeski, T.M., 1998, Methods of analysis by the U.S. Geological Survey National Water Quality Laboratory-Determination of elements in whole-water digests using inductively coupled plasma-optical emission spectrometry and inductively coupled plasma-mass spectrometry: U.S. Geological Survey Open-File Report 98-165, $101 \mathrm{p}$.

Gibson, A.M., 1972, Wilderness bonanza-The Tri-State district of Missouri, Kansas, and Oklahoma: Norman, Oklahoma, University of Oklahoma Press, 362 p.

Gibson, A.M., 1982, Lead and zinc in Morris, J.W., ed., Drill bits, picks, and shovels - A history of mineral resources in Oklahoma: Oklahoma City, Oklahoma, Oklahoma Historical Society, 201 p. 
Gray, K.A., 2004, Phytoremediation of lead: Evanston, Ill., Northwestern University, 4 p., available online at URL: http://www.civil.northwestern.edu/EHE/HTML_KAG/ Kimweb/MEOP/Section4.htm. (Accessed on Sept. 11, 2004.)

Helsel, D.R., and Hirsch, R.M., 1993, Statistical methods in water resources: Amsterdam, Elsevier, 529 p.

Hem, J.D., 1992, Study and interpretation of the chemical characteristics of natural water ( $3 \mathrm{~d}$ ed.): U.S. Geological Survey Water-Supply Paper 2254, 263 p.

Insightful Corporation, 2005, S-Plus 7.0 for Windows Professional Developer Edition with Release 3.0 of the U.S. Geological Survey S-Plus library: Seattle, Washington

Karmaus, Wifried, Brooks, K.R., Nebe, Thomas, Witten, Jutta, Obi-Osius, Nadia, and Kruse, Hermann, 2005, Immune function biomarkers in children exposed to lead and organochlorine compounds-A cross-sectional study: Environmental Health, v. 4, no. 5, 22 p.

Lanphear, B.P., Hornung, Richard, Khoury, Jane, Yolton, Kimberly, Baghurst, Peter, Bellinger, D.C., Canfield, R.L., Dietrich, K.N., Bornschein, Robert, Greene, Tom, Rothenberg, S.J., Needleman, H.L., Schnaas, Lourdes, Wasserman, Gail, Graziano, Joseph, and Roberts, Russel, 2005, Low-level environmental lead exposure and children's intellectual function-An international pooled analysis: Environmental Health Perspectives, v. 113, no. 7, p. 894-899

Martin, T.D., Brockhoff, C.A., Creed, J.T., and EMMC Methods Work Group, 1994, Method 200.7-Determination of metals and trace elements in water and wastes by inductively-coupled plasma-atomic emission spectrometry: U.S. Environmental Protection Agency, Office of Research and Development, Environmental Monitoring Systems Laboratory, 58 p., available online at URL: http://www.epa.gov/ waterscience/methods/method/files/200_7.pdf. (Accessed on June 30, 2008.)

McKnight, E.T., and Fischer, R.P., 1970, Geology and ore deposits of the Picher field, Oklahoma and Kansas: U.S. Geological Survey Professional Paper 588, 165 p.

Morel, F.M.M., and Hering, J.G., 1993, Principles and applications of aquatic chemistry: New York, John Wiley and Sons, 588 p.

New South Wales Environmental Protection Agency, 2003, How lead gets into people: New South Wales Environmental Protection Agency, available at URL: http://www.epa. nsw.gov.au/leadsafe/leadinf3.htm. (Accessed on Sept. 11, 2004.)
North Dakota Department of Health, 2004, Lead-based paint: North Dakota Department of Health_-Division of Air Quality, available online at URL: http://www.health.state.nd.us. ndhd/environ/ee/RAD/LBP/info.htm. (Accessed on Nov. 22, 2004.)

Oberg, K.A., Morlock, S.E., and Caldwell, W.S., 2005, Quality-assurance plan for discharge measurements using acoustic Doppler current profilers: U.S. Geological Survey Scientific Investigations Report 2005-5183, 35 p.

O’Day, P.A.,Carroll, S.A., and Waychunas, G.A., 1998, Rock-water interactions controlling zinc, cadmium, and lead concentrations in surface waters and sediments, U.S. Tri-State mining district. 1. Molecular identification using X-ray absorption spectroscopy: Environmental Science and Technology, v. 32, no. 7, p. 943-955.

Oklahoma Department of Environmental Quality, 2003, Fish tissue metals analysis in the Tri-State mining area, FY2003, Final Report: available online at URL: http:// www.deq.state.ok.us/LPDnew/Tarcreek/GovrTaskForcel TarCreekFishReport.pdf. (Accessed on March 6, 2008.)

Oklahoma Department of Environmental Quality, 2008, Surface-water quality in the Grand-Neosho River Basin, Northeastern Oklahoma, Draft Final Report: Oklahoma Department of Environmental Quality, I-006500-05 Project $\# 4,20$ p.

Paradis, Suzanne, and Hannigan, Peter, and Dewing, Keith, 2006, Mineral Deposits of Canada-Mississippi Valley-type lead-zinc deposits (MVT): Geological Survey of Canada, available online at URL: http://gsc.nrcan.gc.ca/mindep/ synth_dep/mvt/pdf/deposit_synthesis_mvt.paradis.pdf. (Accessed on July 24, 2008.)

Parkhurst, D.L., 1987, Chemical analyses of water samples from the Picher mining area, northeast Oklahoma: U.S. Geological Survey Open-File Report 87-453, 43 p.

Parkhurst, D.L.; Doughten, Michael; and Hearn, P.P., Jr., 1988, Chemical analyses of stream sediment in the Tar Creek basin of the Picher mining area, northeast Oklahoma: U.S. Geological Survey Open-File Report 88-469, 13 p.

Radtke, D.B., 1997, Bottom-material samples: U.S. Geological Survey, Techniques of Water-Resources Investigations, book 9, chap. A8 [variously paged].

Rantz, S.E., and others, 1982, Measurement and computation of streamflow-Volume 1. Measurement of stage and outflow: U.S. Geological Survey Water-Supply Paper 2175, $284 \mathrm{p}$.

Reed, E.W., Schoff, S.L., and Branson, C.C., 1955, Groundwater resources of Ottawa County, Oklahoma: Oklahoma Geological Survey, Bulletin 72, 203 p. 
Robertson, David, 2006, Hard as the rock itself-Place and identity in the American mining town: University Press of Colorado, $216 \mathrm{p}$.

Schaider, L.A., Senn, D.B., Brabander, D.J., McCarthy, K.D., and Shine, J.P., 2007, Characterization of zinc, lead, and cadmium in mine waste-Implications for transport, exposure, and bioavailability: Environmental Science and Technology, v. 41, no. 11, p. 4,164-4,171.

State of Oklahoma, 2000a, Governor Frank Keating's Tar Creek Superfund Task Force, Final Report: Office of Secretary of Environment, October 1, 2000, 26 p.

State of Oklahoma, 2000b, Governor Frank Keating's Tar Creek Superfund Task Force, Health Effects Subcommittee, Final Report: Office of Secretary of the Environment, August 1, 2000, 3 p.

State of Oklahoma, 2002, Oklahoma plan for Tar Creek, available online at URL: http://www.deq.state.ok.us/lpdnew/ Tarcreek/Okplan.pdf. (Accessed on Sept. 28, 2007.)

Stumm, Werner, and Morgan, J.J., 1981, Aquatic chemistry, 2d ed.: New York, John Wiley and Sons, 780 p.

Timme, P.J., 1995, National Water Quality Laboratory 1995 services catalog: U.S. Geological Survey Open-File Report 95-352, p. 92.

U.S. Department of Agriculture, 2003, County mosaic images: U.S. Department of Agriculture, Farm Service Agency, Aerial Photography Field Office, National Agriculture Imagery Program, available online at URL:ftp://ftp.okcc.state.ok.us/ gis/County/2003/Ottawa/. (Accessed on Sept. 22, 2008.)
U.S. Department of Agriculture, 2006, County mosaic images: U.S. Department of Agriculture, Farm Service Agency, Aerial Photography Field Office, National Agriculture Imagery Program, available online at URL: ftp://ftp.okcc.state.ok.us/ GIS/County/2006/Ottawa/. (Accessed on Oct. 1, 2008.)

U.S. Environmental Protection Agency, 1998, Microwave assisted acid digestion of sediments, sludges, soils, and oils: U.S. Environmental Protection Agency Method 3051A, revision 1, January 1998, 25 p.

U.S. Environmental Protection Agency, 2006, National Recommended Water Quality Criteria: U.S. Environmental Protection Agency, 25 p.

Wilde, F.D., Radtke, D.B., Gibs, Jacobs, and Iwatsubo, R.T., eds., 1998a, National field manual for the collection of water-quality data - Collection of water-quality samples: U.S. Geological Survey Techniques of Water-Resources Investigations, book 9, chap. A4 [variously paged].

Wilde, F.D., Radtke, D.B., Gibs, Jacobs, and Iwatsubo, R.T., eds., 1998b, National field manual for the collection of water-quality data-Cleaning of equipment for water-quality samples: U.S. Geological Survey Techniques of WaterResources Investigations, book 9, chap. A3 [variously paged].

World Health Organization, 1996, Trace elements in human nutrition and health: World Health Organization, 361 p. 